\title{
O GÊNERO MICONIA RUIZ \& PAV. (MELASTOMATACEAE) NO ESTADO DE SÃO PAULO
}

\author{
Angela Borges Martins ${ }^{1}$ \\ João Semir ${ }^{1}$ \\ Renato Goldenberg ${ }^{1,2}$ \\ Eneida Martins 1.2
}

Recebido em 10/1/95. Aceito em 7/11/96.

\begin{abstract}
RESUMO - (O Gênero Miconia Ruiz \& Pav. (Melastomataceae) no Estado de São Paulo). Este trabalho trata das espécies de Miconia coletadas no Estado de São Paulo. As 53 espécies aqui relacionadas, descritas e comentadas representam, provavelmente, todos os táxons do gênero até o momento coletados neste Estado.
\end{abstract}

Palavras-chave: Melastomataceae, Miconia, florística, São Paulo.

\begin{abstract}
The Genus Miconia Ruiz \& Pav. (Melastomataceae) in São Paulo State). The present paper deals with the species of Miconia occuring in the Brazilian State of São Paulo. The 53 species listed and described here probably represent all taxa of the genus collected in this State.
\end{abstract}

Key-words: Melastomataceae, Miconia, floristics, São Paulo.

\section{Introdução}

As Melastomataceae constituem uma das famílias mais importantes da flora neotropical, com 4.200 a 5.000 espécies pertencentes a 11 tribos e 185 gêneros (Renner 1993). Miconia é, sem dúvida, o maior gênero, com aproximadamente 1.000 espécies distribuídas ao longo da América tropical e especialmente concentradas nos Andes (Judd \& Skean 1991; Wurdack \& Renner 1993). No Brasil estão representadas por cerca de 250 espécies, das quais 53 foram coletadas no Estado de São Paulo. Nenhum tratamento abrangente surgiu desde a monografia familial de Cogniaux (1891). O gênero mostra grande diversidade nos tricomas (Wurdack 1986), anteras e morfologia das sementes, podendo ser caracterizado, entre os demais da tribo Miconieae, por suas inflorescências terminais multifloras, cimosas, pétalas usualmente

Depart. Botânica - IB - UNICAMP, C.P. 6109; CEP 13084-100, Campinas, SP

2 Pós-Graduação, Bolsistas da CAPES 
arredondadas a obtusas no ápice, dentes externos do cálice geralmente inconspícuos e folhas destituídas de formicários. Segundo Judd \& Skean (1991), estas características são todas simplesiomórficas e, por isso, o gênero tem sido o repositário de espécies feneticamente primitivas e cladisticamente basais de diversas clades, cujos membros derivados são genericamente segregados. As seções tradicionalmente reconhecidas são baseadas em diversas características dos estames, como a morfologia das anteras e do conectivo, número de poros e tipo de deiscência, associados à morfologia do hipanto e cálice (Triana 1871; Cogniaux 1887/1888 e 1891; Judd 1986). Como os trabalhos recentes relativos ao gênero limitaram-se, até agora, a levantamentos florísticos (Baumgratz 1980, 1982 e 1984; Pereira 1964; Wurdack 1962, 1973 e 1980, Wurdack \& Renner 1993) ou de posicionamento tribal (Judd 1986 e 1989, Judd \& Skean 1991), os limites seccionais e específicos permanecem controvertidos. Embora o presente estudo seja restrito a um grupo relativamente pequeno de espécies, ficou bastante claro que novos limites seccionais e específicos deverão ser estabelecidos, quando dados adicionais provenientes de um estudo mais amplo do gênero e de suas espécies se tornarem disponíveis. Neste trabalho, estas alterações taxonômicas e nomenclaturais, reconhecidas como necessárias, não foram efetuadas.

Diante da inexistência de estudos atuais referentes ao gênero Miconia no Estado de São Paulo, o que tem dificultado a identificação das espécies, o objetivo deste trabalho é documentar e descrever as espécies paulistas, fornecer dados sobre a distribuição geográfica, bem como uma chave analítica para o reconhecimento das espécies.

\section{Material e métodos}

O material utilizado neste trabalho foi obtido nos herbários C, ESA, HRCB, IAC, RB, SP, SPF, UEC e FFCLRP-USP. Além disso, várias coletas e observações de campo foram realizadas em diversos municípios do Estado de São Paulo. Na relação de material examinado, apenas um espécime é citado para cada localidade; no caso de espécies pouco coletadas, todo o material existente foi relacionado. As descrições apresentadas mostram somente a variação encontrada em exemplares coletados em São Paulo, complementadas, quando necessário, com informações obtidas em materiais adicionais de outras localidades e na bibliografia. A terminologia adotada para a nervação foliar é a de Hickey (1974). Os grupos artificiais de espécies usados na chave de identificação seguem a organização utilizada por Wurdack (1973 e 1980) e Wurdack \& Renner (1993). O posicionamento das espécies nas seções segue Cogniaux (1887/1888).

Descrição do Gênero

Miconia Ruiz \& Pav., Fl. Peruv. Prodr.: 60. 1794, nom. cons.

Espécie tipo: M. triplinervis Ruiz \& Pav., typ. cons. 
Arbustos ou árvores com indumento variável, raramente glabros. Folhas coriáceas a membranáceas, pecioladas ou sésseis, com venação acródroma basal ou supra-basal. Inflorescências cimosas terminais ou pseudo-laterais, raramente axilares. Flores geralmente pentâmeras, raras vezes tetrâmeras ou hexâmeras; hipanto cilíndrico; cálice duplo, em geral regularmente lobado e usualmente com lacínias externas pouco conspícuas, persistente no fruto ou caduco; pétalas brancas, raramente rosadas, pequenas, arredondadas ou retusas no ápice, raramente apiculadas, glabras ou papilosas, ciliadas ou não; estames dimórficos ou isomórficos; filetes em geral glabros; anteras de forma variável, amarelas, brancas ou roxas; conectivo simples ou basalmente prolongado, muitas vezes com apêndices dorsais ou ventrais; tecas uniporosas, algumas vezes 2 ou 4 porosas ou rimosas; ovário (2-) 3 - 5 locular, semi-ínfero a completamente ínfero; fruto bacáceo; sementes numerosas ou apenas uma por lóculo, piramidais a ovóideas, lisas ou tuberculadas.

Chave para a identificação das espécies

1. Folhas adultas com face inferior glabra, exceto por indumento presente às vezes apenas sobre as nervuras

GRUPO A

1. Folhas adultas com face inferior permanentemente recoberta por indumento $\mathrm{b}$

2. Face inferior das folhas com superfície visível, apesar da presença do indumento, quando observada em estereomicroscópio GRUPO B

2. Face inferior das folhas com superfície não visível, completamente recoberta pelo indumento GRUPO C

\section{GRUPO A}

1. Folhas com ao menos um par de nervuras suprabasais 2

1. Folhas com todos os pares de nervuras basais 13

2. Anteras rimosas até a base da teca 3

2. Anteras poricidas (em M. sellowiana com poros muito amplos e inclinados, semelhantes a rimas, mas que atingem apenas um terço da teca) 4

3. Cálice com lacínias externas formadas por dentículos muito reduzidos, muito menores que as lacínias internas 26. M. hymenonervia

3. Cálice com lacínias externas triangulares, de tamanho semelhante ou levemente menores que as internas 43. $M$. rigidiuscula

4. Estames com filetes esparsamente glandulosos. Cálice com verticilo externo formado por lacínias longas, subuladas 30. M. langsdorffii

4. Estames com filetes eglandulosos. Cálice com o verticilo externo inconspícuo ou formado por dentículos ou lacínias curtas, triangulares, mas nunca longas e subuladas 5 
5. Nós dos ramos com projeções interpeciolares, à semelhança de estípulas

5. Nós dos ramos destituídos destas projeções 6 12. M. cinnamomifolia

6. Nervuras na face inferior das folhas unidas na base por membrana 7

6. Nervuras na face inferior das folhas com a base livre 9

7. Folhas com margem serreada no terço superior; ovário com ápice papiloso 46. M. sellowiana

7. Folhas com margem inteira, repanda ou crenado-denticulada; ovário com ápice glabro 8

8. Estames sempre 10; bractéolas persistentes

36. M. paniculata

8. Estames 12 ou mais; bractéolas caducas 19. M. doriana

9. Estames dimórficos, apresentando conectivo com projeção basal ampla, contínua da região ventral à dorsal em pelo menos um dos verticilos

9. M. chamissois

9. Estames iguais ou dimórficos, com conectivo ventralmente bilobado ou com projeção dorsal em forma de cálcar 10

10. Inflorescências terminais e laterais, com no máximo $4 \mathrm{~cm}$ de comprimento 51. M. tristis

10. Inflorescências sempre terminais, excedendo $4 \mathrm{~cm}$ de comprimento 11

11. Folhas com margem repanda e ciliolada .... 8.M. centrodesma

11. Folhas com margem inteira, revoluta ondulada ou até repandadenticulada, nunca ciliolada 12

12. Lâminas $9-20 \mathrm{~cm}$ de comprimento, base atenuada e longamente decurrente, pecíolo alado; ovário curtamente glanduloso no ápice 40. M. prasina

12. Lâminas $2,5-10 \mathrm{~cm}$ de comprimento, base subcordada, arredondada até estreitamente atenuada, pecíolos não alados; ovário glabro

13. Anteras rimosas até a base da teca 33.M. ligustroides

43. M. rigidiuscula

13. Anteras poricidas (em $M$. latecrenata com poros muito amplos e inclinados, semelhantes a rimas, mas que atingem apenas a metade da teca) 14

14. Anteras com 4 poros 50.M. theaezans

14. Anteras com 1 ou 2 poros 15

15. Tecas com 4-7mm de comprimento 16

15. Tecas com 1-3mm de comprimento 17

16. Cálice com lacínias externas longas, subuladas, maiores que as internas

30. M. langsdorffii

16. Cálice com lacínias externas triangulares, iguais ou menores que as internas ... 29. M. jucunda 
17. Anteras com poros muito amplos e inclinados, que podem ser interpretados como rimas, mas atingindo metade da teca 31.M. latecrenata

17. Anteras com poros não muito amplos e inclinados, semelhantes a rimas 18

18. Cálice com verticilo interno formado por lacínias bem definidas, com lobos arredondados ou triangulares 19

18. Cálice truncado, sem lobos distintos 23

19. Inflorescências terminais e laterais

51.M. tristis

19. Inflorescências sempre terminais 20

20. Ovário com o ápice levemente estrelado-furfuráceo; tecas ca. $1,5 \mathrm{~mm}$, conectivo giboso e calcarado no dorso, ventralmente prolongado abaixo das tecas

38. M. petropolitana

20. Ovário com ápice glabro; tecas ca. $2,5 \mathrm{~mm}$ ou menos, neste caso com conectivos nunca gibosos, com projeções arredondadas, dorsais, na sua base, ou com um pequeno cálcar dorsal e duas aurículas ventrais 21

21. Hipanto, eixos das inflorescências e ramos novos densamente estrelado-furfuráceos; pedicelos e nós das inflorescências com tufos de tricomas dendríticos de ramos curtos, ou simples

7. M. cecidophora

21. Hipanto, eixos das inflorescências e ramos novos glabros ou recobertos por indumento estrelado furfuráceo; pedicelos e nós das inflorescências sem tufos de tricomas dendríticos 22

22. Cálice com lacínias internas cilioladas; pétalas com ápice esparsamente ciliado-glanduloso

35. M. minutiflora

22. Cálice com lacínias não cilioladas; pétalas glabras

33. M. ligustroides

23. Hipanto glabro; ovário com ápice glabro .. 13.M. collatata

23. Hipanto densa a moderadamente recoberto por tricomas estrelados, ovário com ápice esparsamente glanduloso 5.M. calvescens

\section{GRUPO B}

1. Folhas com ao menos um par de nervuras suprabasais 2

1. Folhas com todos os pares de nervuras basais 11

2. Anteras rimosas totalmente ou quase até a base 3

2. Anteras poricidas 4

3. Folhas com face inferior apresentando tricomas híspidos, mesclados com tricomas estrelado-furfuráceos esparsos, principalmente sobre as nervuras 23. M. hispida

3. Folhas com face inferior apresentando tricomas estrelados a estipitados, nunca híspidos 52. M. urophylla

4. Folhas com face inferior apresentando tricomas simples (setulosos, seríceos ou lanoso-vilosos), mesclados ou não com tricomas estrela$\operatorname{dos} 5$ 
4. Folhas com face inferior apresentando indumento exclusivamente estrelado ou lepidoto 6

5. Hipanto e nervuras na face inferior das folhas revestidos por indumento estrelado-furfuráceo, ocráceo a ferrugíneo, mesclado com tricomas setulosos a híspidos

27. M. ibaguensis

5. Hipanto e nervuras na face inferior das folhas lanoso-vilosos, indumento nunca mesclado com tricomas estrelados 41. M. pseudonervosa 6. Nervuras na face inferior das folhas unidas na base por membrana 7 6. Nervuras na face inferior das folhas com a base livre 9

7. Estames sempre 10; bractéolas persistentes

7. Estames 12 ou mais; bractéolas caducas 36. M. paniculata

8. Cálice com lacínias externas longas, triangulares 19. M. doriana 42. $M$. racemifera

8. Cálice com lacínias externas muito curtas, formando dentículos pouco conspícuos 9

9. Flores dispostas em panículas 20. M. elegans

9. Flores congestas, formando glomérulos que se dispõem ao longo ou nas extremidades dos ramos secundários das inflorescências 10

10. Folhas oblanceoladas a obovadas, com base longamente decurrente; inflorescências com todos os ramos secundários curtos (até $2,5 \mathrm{~cm}$ ) 17. M. discolor

10. Folhas oblongas a elípticas, com base atenuada; inflorescências com ramos secundários basais longos (3,5$12 \mathrm{~cm})$ 45.M. saldanhaei

11. Flores dispostas em panículas com ramificações escorpióides ou não 12

11. Flores congestas, formando séries de glomérulos ao longo dos ramos secundários ou glomérulos isolados nos ápices dos ramos secundários das inflorescências 20

12. Inflorescências com ramificações escorpióides 13

12. Inflorescências com ramificações não escorpióides 14

13. Face inferior das folhas com indumento dendrítico-estrelado 53. M. valtherii

13. Face inferior das folhas com indumento lepidoto-estrelado 32. M. lepidota

14. Anteras rimosas até a base da teca 49. M. tentaculifera

14. Anteras poricidas (em M. latecrenata com poros muito amplos e inclinados, semelhantes a rimas, mas que atingem apenas a metade da teca) 15 
15. Anteras com poros muito amplos e inclinados, que podem ser interpretados como rimas, mas atingindo metade da teca .................................... 31. M. latecrenata

15. Anteras com poros não muito amplos e inclinados, semelhantes a rimas 16

16. Estames com tecas curtas (ca. $1 \mathrm{~mm}$ ), biporosas 28. M. inconspicua

16. Estames com tecas longas ( $2 \mathrm{~mm}$ ou mais), uniporosas 17

17. Tecas com $5,5-7 \mathrm{~mm}$ de comprimento

29. M. jucunda

17. Tecas com no máximo $3 \mathrm{~mm}$ de comprimento 18

18. Lâminas $10-24 \mathrm{~cm}$ de comprimento; pedicelos e nós dos ramos das inflorescências com tufos de tricomas dentríticos, de ramos curtos ou simples

7.M. cecidophora

18. Lâminas $4-14 \mathrm{~cm}$ de comprimento; indumento acima descrito ausente 19

19. Folhas com base arredondada e ápice agudo a curtamente acuminado; face inferior com indumento ferrugíneo, estrelado-estipitado 44. M. rubiginosa

19. Folhas com base atenuada e ápice acuminado a caudado; face inferior com indumento canescente a ocráceo, estrelado-furfuráceo 16. M. depauperata 20. Cálice com verticilo externo formado por lacínias mais compridas que as do verticilo interno

42. M. racemifera

20. Cálice com verticilo externo formado por dentículos mais curtos que as lacínias internas 21

21. Ovário com indumento no ápice

45.M. saldanhaei

21. Ovário com ápice glabro 22

22. Flores tetrâmeras, estames com conectivo inapendiculado

6.M. castanaeflora

22. Flores pentâmeras, estames com conectivo curtamente calcarado no dorso e com aurículas ventrais curtas 39. M. pohliana

\section{GRUPO C}

1. Folhas com ao menos um par de nervuras suprabasais 2

1. Folhas com todos os pares de nervuras basais 11

2. Estames com conectivo ampla e basalmente expandido no dorso e ventralmente projetado em aurículas arredondadas, contínuo da região ventral à dorsal 1.M. albicans

2. Estames com conectivo inapendiculado, ou com projeção dorsal em forma de cálcar, podendo apresentar aurículas ventrais, mas sem formar uma projeção ampla, contínua da região ventral à dorsal 3

3. Flores dispostas em panículas, com ramificações não escorpióides 4

3. Flores congestas, dispostas em cimas escorpióides muito curtas ou em glomérulos ao longo ou na extremidade dos ramos secundários das inflorescências 5 
4. Lâminas 13-23x6-9,5cm; estames roxos, tecas ca. $7 \mathrm{~mm}$ 24. M. holosericea

4. Lâminas $4-13 \times 1-4 \mathrm{~cm}$; estames brancos, tecas ca. $1,5 \mathrm{~mm}$ 15. M. cubatanensis 5. Ovário com ápice glabro 6

5. Ovário com ápice recoberto por indumento 9

6. Folhas com base arredondada a subcordada

4.M. cabussu

6. Folhas com base aguda, atenuada até decurrente 7

7. Inflorescências com todos os ramos secundários curtos (até $2,5 \mathrm{~cm}$ ), geralmente apresentando apenas um glomérulo na sua extremidade

17. M. discolor

7. Inflorescências com ramos secundários basais longos $(3,5-15 \mathrm{~cm})$, ao longo dos quais se dispõem séries de glomérulos ou ramos terciários, com 1-3 glomérulos 8

8. Folhas subsésseis, com base longamente atenuada e decurrente

2.M. brunnea

8. Folhas distintamente pecioladas, com base atenuada a levemente decurrente 10. M. chartacea

9. Estames biporosos, os ante-pétalos com conectivo calcarado no dorso 25.M. hyemalis

9. Estames uniporosos, com conectivo inapendiculado ou com dois lobos curtos, ventrais 10

10. Folhas com base atenuada a decurrente; flores pentâmeras...

3.M. budlejoides

10. Folhas com base arredondada; flores tetrâmeras

37. M. pepericarpa

11. Flores dispostas em panículas, com ramificações não escorpióides 12

11. Flores dispostas de forma congesta ao longo ou na extremidade dos ramos secundários das inflorescências, ou ainda em panículas com ramificações escorpióides 16

12. Anteras com tecas longas $(5-8 \mathrm{~mm}) \quad 13$

12. Anteras com com tecas pequenas (1-2mm) 15

13. Anteras com tecas amarelas .... 18. M. dodecandra

13. Anteras com tecas roxas ou purpúreas 14

14. Folhas com margem serrulada e base cor-dada 47. M. serrulata

14. Folhas com margem sinuosa e base arredondada 24. M. holosericea

15. Estames uniporosos; conectivo ventralmente inapendiculado

15. M. cubatanensis

15. Estames biporosos; conectivo ventralmente com duas aurículas curtas ou largas 28. M. inconspicua 
16. Folhas com margem denteada 17

16. Folhas com margem lisa, ondulada, crenulada, levemente denticulada ou inconspicuamente serreada, mas neste caso ciliada 18

17. Inflorescências com 3-6cm de comprimento; estames biporosos

25. M. hyemalis

17. Inflorescências com 6-14cm de comprimento; estames uniporosos

11. M. cinerascens

18. Folhas ovais, oblongas, largamente elípticas até suborbiculares, com margem serreada e ciliada

34. M. macrothyrsa

18. Folhas elípticas, oblongas, obovadas ou lanceoladas, com margem inteira, crenulada ou levemente denticulada, mas nunca ciliada 19

19. Ovário com indumento no ápice

37. M. pepericarpa

19. Ovário com ápice glabro 20

20. Panículas de glomérulos; flores tetrâmeras 21

20. Panículas escorpióides; flores pentâmeras 22

21. Folhas membranáceas a cartáceas; cálice com lacínias internas triangulares agudas e verticilo externo, constituído por pequenos dentículos

6. M. castaneaeflora

21. Folhas coriáceas; cálice com lacínias internas repandas a arredondadas e verticilo externo formado por lacínias triangulares, curtas 14. M. corallina

22. Árvores $8-15 \mathrm{~m}$ de altura, ocorrendo em florestas 32. M. lepidota

22. Arbustos até $2,5 \mathrm{~m}$ de altura, ocorrendo em cerrado 23 23. Pétalas com margem ciliada 24

23. Pétalas com margem não ciliada 25

24. Folhas sésseis a subsésseis, com base arredondada a cordada, ápice arredondado a agudo, nunca acuminado 21. M. fallax

24. Folhas distintamente pecioladas $(0,5-2,5 \mathrm{~cm})$, com base obtusa e ápice arredondado a curtamente acuminado 48.M. stenostachya

25. Ramos grossos, com inflorescências muito alongadas 22. M. ferruginata

25. Ramos não engrossados, com inflorescências piramidais ou cilíndricas

1.M. albicans

Descrições das espécies

1. Miconia albicans (Sw.) Triana, Trans. Linn. Soc. Bot. 28: 116. 1871. Melastoma albicans Sw. Prodr. 70. 1788. Seção Miconia-Seriatiflorae.

Fig. 1a 
Arbustos até 2,5m. Ramos, pecíolos, eixos das inflorescências, brácteas, hipanto e cálice densamente revestidos por indumento tomentoso, canescente ou ferrugíneo. Folhas com pecíolos $0,5-2 \mathrm{~cm}$; lâmina 5-15×2,5-6cm, coriácea, elíptica, oblonga ou obovada, base arredondada a subcordada, ápice obtuso, agudo até curtamente acuminado, margem levemente ondulado-crenulada, nervuras acródromas basais ou ocasionalmente suprabasais; face superior das folhas jovens densamente tomentosa, posteriormente glabra, face inferior densamente tomentosa. Panículas escorpióides, ca. $15 \mathrm{~cm}$, curtas. Flores pentâmeras; hipanto $2,5 \mathrm{~mm}$; cálice persistente, com lacínias internas e externas fundidas, largamente triangulares; pétalas brancas. Estames dimórficos, brancos; tecas ca. $3 \mathrm{~mm}$, uniporosas; conectivo bastante espessado no dorso, nos estames ante-sépalos muito prolongado abaixo das tecas, ampla e basalmente expandido no dorso e ventralmente projetado em aurículas largas, contínuo da região ventral à dorsal, nos ante-pétalos bastante prolongado em cálcar dorsal alargado e ventralmente projetado em aurículas arredondadas. Ovário 3-locular, glabro; estilete abruptamente alargado no ápice. Baga verde-jade quando madura; sementes numerosas, pequenas, ca. 10 por lóculo.

Distribuição e habitat: Ocorre desde o sul do México e Antilhas até o Paraguai. No Brasil distribui-se por quase todos os Estados, de Roraima e Amazonas até o Paraná. Esta espécie é característica de cerrados e savanas, mas também é encontrada em vegetação litorânea.

Material selecionado examinado: Brasil, São Paulo: Águas de Santa Bárbara, 14/VIII/ 1989, Meira Neto 423 (UEC); Angatuba, 19/XI/1983, Ratter \& Argent 4900 (UEC); Anhembi, 25/V/1979, Assumpção 7542 (UEC); Avaré, 03/IX/1984, Pirani et al. 892 (UEC); Bauru, 07/VII/1994, Pirani 3294 et al. (UEC); Botucatu, 10/X/1985, Amaral Jr. et al. 26 (UEC); Cajuru, 24/IX/1989, Sciamarelli \& Nunes 281 (UEC); Campinas, 02/X/1969, Souza s.n. (IAC 2711); Casa Branca, 15/1X/1969, Souza, s.n. (IAC 22364); Heitor Legrú, 19/IX/1938, Gehrt s.n. (SP 3518); Corumbataí, 10/IX/1982, Campos s.n. (UEC 65132); Itirapina, 03/X/1983, César 3472 (UEC); Itu, 13/VII/ 1987, Souza \& Britez 25352 (UEC); Lençóis Paulista, 12/VI/1995, Tamashiro 1059 et al. (UEC); Miguel Calmon, 22/IX/1919, Gehrt s.n. (SP 3637); Moji Guaçu, 07/VII/ 1980, Mantovani 924 (UEC); Mogi Mirim, X/1978, Toledo Filho 10703 (UEC); Pedregulho, 26/VIII/1981, Marcondes-Ferreira et al. 381 (FFCLRP-USP); São Carlos, 30/IV/1980, Semir et al. 11538 (UEC); São José do Rio Preto, 29/IX/1938, Rombouts s.n. (IAC 2711); São Paulo, 11/X/1946, Hoehne s.n. (UEC 65130); São Simão, 29/XI/1960, Mattos 8625(SP); Ubatuba, 16/VI/1985, Yamamoto et al. 17640 (UEC).

Miconia albicans distingue-se de M. fallax DC. e M. stenostachya Schrank \& Mart. ex DC. por apresentar indumento tomentoso na face superior das folhas jovens, pelos frutos verde-jade quando maduros, estiletes abruptamente alargados e estames brancos e desiguais nos dois ciclos. Em M. fallax e M. stenostachya os frutos maduros 
são atropurpúreos, o estilete é levemente alargado no ápice, as anteras amarelas sem conectivo prolongado e as pétalas apresentam margem ciliado-glandulosa. Os materiais citados por Hoehne (1922) como M. argyrophylla DC. - Gehrt s.n. (SP 3637 e 3618) - pertencem a M. albicans.

2. Miconia brunnea Mart. ex DC., Prodr. 3: 184. 1828. Seção Glossocentrum.

Árvores até 10m. Ramos achatados, decussados, densamente recobertos nas partes jovens por indumento dendrítico ou estrelado, ocráceo a ferrugíneo, assim como os pecíolos, eixos das inflorescências, hipanto e cálice. Folhas subsésseis; lâmina 30-40x 14-19cm, cartácea, elíptico-oblonga a oboval, base longamente atenuada a decurrente, ápice obtuso, margem inteira, nervuras acródromas suprabasais, acrescidas por um par marginal basal e decurrente; face superior das folhas jovens com tricomas estrelados, depois glabra, à exceção das nervuras, face inferior densamente recoberta por indumento estrelado ou dendrítico ocráceo a ferrugíneo. Panículas de glomérulos, até $30 \mathrm{~cm}$; ramos secundários basais longos $(10-15 \mathrm{~cm})$. Flores pentâmeras; hipanto ca. $2 \mathrm{~mm}$; cálice caduco, com verticilo interno sem lobos distintos, externo formado por dentículos muito reduzidos; pétalas brancas. Estames subisomórficos; tecas ca. $2 \mathrm{~mm}$, uniporosas; conectivo pouco prolongado abaixo das tecas, bastante espessado no dorso, estames ante-sépalos dorsalmente bituberculados ou com cálcar arredondado curto, estames ante-pétalos inapendiculados. Ovário 2-3 locular, glabro; estilete filiforme. Baga com (1-)2-3 sementes grandes.

Distribuição e habitat: Ocorre em Minas Gerais, Rio de Janeiro e São Paulo, em formações florestais de altitudes elevadas.

Material selecionado examinado: Brasil, São Paulo: Loreto, XII/1915, Vecchi 215 (RB) ou Navarro de Andrade 6556 (Ver Hoehne 1922); Paranapiacaba, 25/X/1960, Handro 963 (SP); Qủeluz, 07/IV/1995, Goldenberg \& Belinello 77 (UEC); São José dos Campos, I/1986, Silva 1373 \& Capellari Jr. sn. (UEC); São Paulo, VI/1980, Chiea et al. 120 (SP).

3. Miconia budlejoides Triana, Trans. Linn. Soc. Bot. 28: 118. 1871. Seção Glossocentrum.

Arbustos a árvores 2-5m. Ramos, pecíolos, hipanto e cálice recobertos por indumento lepidoto; eixos das inflorescências com indumento entremeado por tricomas dendríticos. Folhas com pecíolo $1-2,5 \mathrm{~cm}$; lâmina $9-24 \times 2-8,5 \mathrm{~cm}$, cartácea, elíptica a oblongo-elíptica ou oval-lanceolada, base atenuada a decurrente, ápice agudo a acuminado, margem repanda, nervuras acródromas suprabasais, acrescidas por um par marginal, basal; face superior das folhas jovens com tricomas lepidotos e curtamente estrelados, depois glabra, face inferior densamente recoberta por tricomas lepidotos e curtamente estrelados. Panículas de glomérulos, $5-10 \mathrm{~cm}$. Flores pentâmeras; hipanto $2 \mathrm{~mm}$; cálice 
caduco, com lacínias internas repandas; externas constituídas por dentículos; pétalas brancas. Estames isomórficos, amarelos; tecas $2 \mathrm{~mm}$, uniporosas; conectivo curtamente alargado na base, ventralmente com dois lobos muito curtos. Ovário 2-3 locular, ápice piloso; estilete abruptamente alargado no ápice. Baga com 2 sementes por lóculo,

Distribuição e habitat: Ocorre no Rio de Janeiro, São Paulo e Santa Catarina, no subosque e clareiras de formações florestais.

Material selecionado examinado: Brasil, São Paulo: Jundiaí, 08/X/1976, Leitão Filho et al. 3208 (UEC); Queluz, 07/IV/1995, Goldenberg 81 \& Belinello (UEC); Rio Claro, 31/V/1978, Pagano 24 (UEC); São José dos Campos, 19/XI/1986, Silva 1945 \& Capellari Jr. (UEC); São Paulo, 21/II/1976, Davidse \& D'Arcy 10450 (SP).

4. Miconia cabussu Hoehne, Ostenia. 299. 1933. (=Miconia cabuçu Hoehne). Seção Glossocentrum.

Árvores 5-12m. Ramos, pecíolos, eixos das inflorescências, hipanto e cálice densamente recobertos por indumento estrelado-lepidoto. Folhas com pecíolo 2,5-7cm; lâmina $11-29 \times 7-19 \mathrm{~cm}$, cartácea, oval a elíptica, base arredondada a subcordada, ápice obtuso ou agudo até acuminado, margem levemente revoluta, nervuras acródromas suprabasais; face superior das folhas jovens com tricomas estreladolepidotos, depois glabra, face inferior densamente recoberta por indumento estrelado-lepidoto. Panículas de glomérulos, $15-25 \mathrm{~cm}$. Flores pentâmeras ou hexâmeras; hipanto 3-4mm; cálice com lacínias externas truncadas a repandas, internas inconspícuas; pétalas brancas. Estames dimórficos, amarelos; tecas 3-4mm, levemente corrugadas, uniporosas; conectivo dos estames ante-pétalos espessado e basalmente calcarado no dorso, ventralmente projetado em aurículas diminutas, dos ante-sépalos tuberculados no dorso e ventralmente bilobulados. Ovário 3-locular, glabro; estilete levemente espessado no ápice. Baga ca. 3 sementes por lóculo.

Distribuição e habitat: Ocorre na mata atlântica em São Paulo, Paraná e Santa Catarina.

Material selecionado examinado: Brasil, São Paulo: Guarujá, 05/XI/1986, Leitão Filho et al. 18760 (UEC); São Miguel Arcanjo, 08/X/1990, Moraes 270 (UEC); São Paulo, 25/IX/1945, Hoehne s.n. (SPF 11551); 1915, Navarro de Andrade 54 (RB); Ubatuba, 12/XI/1993, Queiroz et al. 30137 (UEC).

De acordo com o artigo 60.4 do ICBN, letras estranhas ao latim clássico devem ser transcritas. Por este motivo, o "ç" utilizado pelo autor da espécie deve ser alterado para "ss". O material citado por Hoehne (1922) como M. organensis Gardn. - Navarro de Andrade 54 - pertence a $M$. cabussu. 
5. Miconia calvescens Schrank \& Mart. ex DC., Prodr. 3: 185. 1828. Seção MiconiaPaniculares.

Fig. $1 \mathrm{~g}$

Arbustos ou árvores até $10 \mathrm{~m}$. Ramos, pecíolos, eixos das inflorescências, hipanto e cálice densa a esparsamente revestidos por indumento estrelado curto, canescente e caduco, às vezes mesclado com tricomas longos, plumosos e esparsos. Folhas com pecíolo $2-4,5 \mathrm{~cm}$; lâmina 11-24x6-12cm, cartácea, elíptica a oval elíptica, base obtusa a arredondada, ápice agudo-acuminado, margem às vezes repanda, nervuras acródromas basais; face superior glabra, inferior das folhas jovens esparsamente revestida por tricomas estrelados, depois glabras, à exceção das nervuras. Panículas até $20 \mathrm{~cm}$. Flores pentâmeras; hipanto ca. $3 \mathrm{~mm}$; cálice persistente, com verticilos interno e externo fundidos, sem lobos distintos; pétalas brancas. Estames isomórficos, brancos; tecas ca. $2 \mathrm{~mm}$, uniporosas; conectivo pouco prolongado abaixo das tecas, dorsalmente espessado e ventralmente biauriculado, com alguns tricomas glandulares nas aurículas. Ovário 3locular, esparsamente glanduloso no ápice; estilete abruptamente alargado no ápice. Baga parda; sementes pequenas e numerosas por lóculo.

Distribuição e habitat: Ocorre no Peru e Brasil, nos Estados do Amazonas, Bahia, Minas Gerais, Espírito Santo, Rio de Janeiro e São Paulo. Coletada em vegetação secundária, em locais úmidos.

Material selecionado examinado: Brasil, São Paulo: Águas da Prata, 23/III/1994, Martins et al. 31397 (UEC); Águas de Lindóia, 09/V/1995, Tamashiro 1036 et al. (UEC); Cajuru, VI/1985, Bernacci 25 (UEC); Campinas, s.d., Goldenberg 48 (UEC); Ipeúna, s.d., Rodrigues \& Zandoval s.n. (ESA 6538); Itirapina, 28/V/1993, Goldenberg 28489 (UEC); Tanabi, 30/VI/1994, Tamashiro et al 308 (UEC); Ubatuba, V/ 1989, Kirizawa \& Correa 2152 (SP).

Foram observadas diferenças morfológicas entre os indivíduos desta espécie coletados no litoral e aqueles do planalto. As plantas do litoral apresentam folhas discolores, com base mais ampla. É possível que constituam táxons distintos.

6. Miconia castaneaeflora Naudin, Ann. Sci. Nat. Bot., ser. 3, 16: 132. 1851. Seção Glossocentrum.

Arbustos ca. $2 \mathrm{~m}$ a árvores $10 \mathrm{~m}$. Ramos jovens, pecíolos, eixos das inflorescências densamente hirtelo-tomentosos. Folhas com pecíolo 2-6mm; lâmina 4-20x4-14cm, membranácea a cartácea, oval, base arredondada a subcordada, ápice agudo e curtamente acuminado, margem levemente denticulada, nervuras acródromas basais; face superior com tricomas estrelado-dendríticos apenas sobre as nervuras, face inferior moderada a densamente hirtelo-tomentosa. Panículas espiciformes de glomérulos, ca. $12 \mathrm{~cm}$. Flores tetrâmeras; hipanto ca. $1 \mathrm{~mm}$; cálice caduco, com lacínias internas triangulares agudas, externas formadas por dentículos, inconspícuos; pétala branca. 
Estames isomórficos, brancos; tecas ca. $1 \mathrm{~mm}$, uniporosas; conectivo inapendiculado. Ovário 1-3 locular, glabro; estilete levemente espessado no ápice. Baga amarela; semente 1 por lóculo.

Distribuição e habitat: Ocorre em Minas Gerais e São Paulo, em formações florestais de altitudes elevadas.

Material selecionado examinado: Brasil, São Paulo: Campos do Jordão, 24/IV/1988, Rubim 605 (UEC); Joanópolis, 14/10/1994, Arbocz 922 (UEC); São Paulo, 15/XI/ 1980, Rosa \& Pires 3063 (SP); 30/XI/1944, Hoehne s.n. (SPF 11442).

7. Miconia cecidophora Naudin, Ann. Sci. Nat. Bot., ser. 3, 16: 166. 1850. Seção Miconia-Paniculares.

Fig. 1h

Arvoretas 3-6m. Ramos jovens, pecíolos, eixos das inflorescências, hipanto e cálice recobertos por indumento denso-estrelado a furfuráceo, canescente, posteriormente glabros; pedicelos e nós dos eixos das inflorescências com tufos de tricomas dendríticos de ramos curtos ou simples. Folhas com pecíolo ca. $1,5 \mathrm{~cm}$; lâmina 10-24 3 3-7,5cm, membranácea, oblongo-lanceolada, base cuneada a atenuada e levemente decurrente, ápice acuminado a caudado, margem repanda a inteira, nervuras acródromas basais; face superior papilosa e glabra, inferior esparsamente revestida por tricomas estrelados ou glabra, com tricomas apenas sobre as nervuras. Panículas até $9 \mathrm{~cm}$, terminais. Flores pentâmeras; hipanto ca. $2 \mathrm{~mm}$; cálice caduco, com lacínias internas obtusas, externas triangulares mais curtas; pétalas brancas. Estames subisomórficos, amarelos; tecas 2-3mm, uniporosas; conectivo bastante espessado no dorso, prolongado abaixo das tecas, nos estames ante-pétalos projetado em cálcar dorsal e aurículas ventrais pouco conspícuas, nos ante-sépalos com expansão dorsal ampla e apêndices ventrais inconspícuos. Ovário 3-locular, glabro; estilete abruptamente alargado no ápice. Baga com 6-7 sementes por lóculo.

Distribuição e habitat: Encontrada até o momento em formações florestais na Bahia, Distrito Federal, Minas Gerais e São Paulo.

Material selecionado examinado: Brasil, São Paulo: Porto Ferreira, VIII/1978, Bertoni 20376 (UEC); Santa Rita do Passa Quatro, X/1978, Martins 10059 (UEC); Teodoro Sampaio, 20/I/1986, Martuscelli 208 (SP).

Possui características vegetativas e distribuição no Estado semelhantes às de $M$. collatata Wurdack, da qual difere pela morfologia do cálice e estames e pelo número de sementes por fruto.

8. Miconia centrodesma Naudin, Ann. Sci. Nat.Bot., ser. 3, 16: 164. 1851. Seção Glossocentrum. 
Arbustos 1,5-2,5m. Ramos, pecíolos, eixos das inflorescências, hipanto e cálice esparsissimamente recobertos por indumento estrelado-furfuráceo caduco. Folhas com pecíolo $1-2,5 \mathrm{~cm}$; lâmina $9-23 \times 5-9 \mathrm{~cm}$, membranácea, elíptica, base atenuada a levemente decurrente, ápice agudo a curtamente acuminado, margem repanda e ciliolada, nervuras acródromas suprabasais; face superior glabra, inferior com tricomas estrelados esparsos apenas sobre as nervuras. Panículas tirsóideas, $5-15 \mathrm{~cm}$, terminais. Flores pentâmeras; hipanto ca. $1,5 \mathrm{~mm}$; cálice persistente, com lacínias internas membranáceas, lobadas, externas em dentículos setulosos; pétalas brancas. Estames isomórficos, amarelos; tecas 1,2-1,8 mm, uniporosas; conectivo prolongado dorsalmente em cálcar basal. Ovário 3-4 locular, inconspicuamente furfuráceo no ápice. Baga vinosa, sementes pequenas e numerosas.

Distribuição e habitat: Ocorre desde a Costa Rica até a Bolívia e leste do Brasil, na Bahia. Sua ocorrência no Estado de São Paulo foi registrada por duas coletas relativamente recentes. Esta disjunção provavelmente pode ser explicada por falta de coletas nas regiões intermediárias.

Material examinado: Brasil, São Paulo: Ubatuba: 17/IV/1979, Jouvin 483 (SP); 30/I/ 1980, Shepherd et al. 10973 (UEC).

Os exemplares coletados em São Paulo apresentam apenas frutos, portanto as características florais mencionadas estão de acordo com Cogniaux (1887/1888) e Wurdack (1973).

9. Miconia chamissois Naudin, Ann. Sci. Nat. Bot., ser. 3, 16: 179. 1851. Seção Miconia-Paniculares.

Arbustos até $3 \mathrm{~m}$, glabros. Folhas com pecíolo 1-2,5cm; lâmina 17-23x5-10cm, coriácea, oval-elíptica, base levemente atenuada a aguda ou arredondada, ápice acuminado, margem inteira, nervuras acródromas suprabasais, assimétricas; ambas as faces glabras. Panículas até $20 \mathrm{~cm}$. Flores pentâmeras; hipanto ca. $2 \mathrm{~mm}$; cálice persistente, com lacínias externas e internas fundidas, truncadas; pétalas brancas. Estames dimórficos, brancos; tecas ca. $2 \mathrm{~mm}$, uniporosas; conectivo bastante espessado no dorso, nos estames ante-sépalos com projeção basal ampla, contínua da região ventral à dorsal, nos ante-pétalos curtamente prolongado e calcarado no dorso, ambos com aurículas ventrais reduzidas. Ovário 3-5 locular, glabro; estilete levemente espessado no ápice. Baga ca. 30 sementes.

Distribuição e habitat: Ocorre na Guiana Francesa, Bolívia e Brasil, nos Estados do Ceará, Piauí, Paraíba, Mato Grosso, Goiás, Distrito Federal, Minas Gerais, Rio de Janeiro, São Paulo e Paraná. Em São Paulo ocorre principalmente em locais alagados, em áreas de domínio de vegetação de cerrado. 
Material selecionado examinado: Brasil, São Paulo: Águas de Santa Bárbara, IV/ 1990, Meira Neto 560 (UEC); Agudos, 25/V/1994, Tamashiro II6 et al. (UEC); Araraquara, 29/XI/1951, Hoehne, s.n. (UEC 65125); Campinas, VIII/1983, Baldassari \& Monteiro Filho 15113 (UEC); Cubatão, II/1988, Leitão Filho et al. 20792 (UEC); Ilha Solteira, VII/1979, Bianco 10267 (UEC); Itapetininga, VII/1977, Gianotti 5514 (UEC); Itirapina, 10/VIII/1992, Goldenberg 28484 (UEC) Jundiaí, 25/VII/ 1968, Aranha I (IAC); Lençóis Paulista, Tamashiro 1091 et al. (UEC); Limeira, 12/ VIII/1948, Hoehne s.n. (UEC 65124); Moji Guaçu, VI/1976, Leitão Filho et al. 2166 (UEC); Santa Maria da Serra, X/1992, Peressim s.n. (UEC 61338); São Simão, s.d., Lima 6267 (IAC).

Comentários em M. prasina (Sw.) DC.

10. Miconia chartacea Triana, Trans. Linn. Soc. Bot. 28: 119. 1871. Seção Glossocentrum.

Arvoretas 3-4m. Ramos, pecíolos, eixos das inflorescências, hipanto e cálice recobertos por indumento denso-estrelado a sublepidoto ocráceo a canescente, entremeado por alguns tricomas dendríticos, ferrugíneos. Folhas com pecíolo 1,5$4 \mathrm{~cm}$; lâmina $8-27 \times 3-10,5 \mathrm{~cm}$, cartácea, elíptica a oblonga ou lanceolada, base atenuada a levemente decurrente, às vezes arredondada, ápice agudo a acuminado, margem inteira sinuosa, nervuras acródromas suprabasais; face superior das folhas jovens furfurácea, depois glabra, à exceção da nervura principal, face inferior densamente recoberta por indumento estrelado a sublepidoto ocráceo a canescente. Panículas de glomérulos, 9-22cm; ramos secundários basais longos $(3,5-12 \mathrm{~cm})$. Flores pentâmeras; hipanto 2-2,5mm; cálice caduco, lacínias internas triangulares, externas formadas por dentículos agudos; pétalas brancas, cuculadas. Estames subisomórficos, brancos; tecas ca. $2 \mathrm{~mm}$, uniporosas; conectivo pouco prolongado abaixo das tecas, espessado no dorso, nos estames ante-sépalos dorsalmente bituberculado ou com cálcar arredondado, nos ante-pétalos inapendiculado. Ovário 2-3 locular, glabro; estilete levemente espessado no ápice. Baga atropurpúrea; sementes grandes, 1-2(-3) por fruto.

Distribuição e habitat: Ocorre na Bahia, Distrito Federal, Minas Gerais, Rio de Janeiro, São Paulo e Santa Catarina. Em São Paulo é encontrada em cerrados e formações florestais.

Material selecionado examinado: Brasil, São Paulo: Cajuru, s.d., Luederwaldt \& Schwebel 2172 (RB); Corumbataí, 10/XII/1983, Campos 123 (UEC); Itirapina, X/ 1983, Cesar 373 (UEC); São Bernardo do Campo, 15/V/1957, Kuhlmann 4086 (SP); Ubatuba, 05/XII/1978, Silva 9164 (UEC); 12/XI/1993, Queiroz et al. 30138 (UEC). 
Miconia chartacea é próxima de $M$. brunnea, porém nesta última as folhas são maiores, com base totalmente decurrente no pecíolo e as nervuras divergem a uma distância de cerca de $7 \mathrm{~cm}$ acima da base; em $M$. chartacea esta distância não ultrapassa $1,5 \mathrm{~cm}$. Os exemplares provenientes de Ubatuba apresentam diferenças em relação aos demais, possuindo folhas oblongas estreitas, com indumento ferrugíneo, nervuras transversais menos salientes na face inferior e inflorescências mais curtas. $\mathrm{O}$ material citado por Hoehne (1922) como M. wildenowii Klotsch - Luederwaldt \& Schebel 2172 - pertence a $M$. chartacea.

\section{Miconia cinerascens Miq., Linnaea 22: 543. 1849. Seção Glossocentrum.}

Arbustos a arvoretas 2-4m. Ramos, pecíolos, eixos das inflorescências, hipanto e cálice densamente recobertos por tricomas estrelado-furfuráceos, adpressos e canescentes. Folhas com pecíolo $1,5-2,5 \mathrm{~mm}$; lâmina $6-13 \times 2-5 \mathrm{~cm}$, cartácea a subcoriácea, elíptico-lanceolada e estreitamente obovada, base arredondada a atenuada, ápice agudo a acuminado, margem denteada exceto na base, nervuras acródromas basais; face superior das folhas jovens estrelado-furfurácea, depois glabra, face inferior densamente recoberta por tricomas estrelado-furfuráceos. Panículas de glomérulos, 6$14 \mathrm{~cm}$. Flores pentâmeras ou hexâmeras; hipanto ca. $2 \mathrm{~mm}$; cálice caduco, com lacínias internas membranáceas, repandas, externas triangulares tuberculadas; pétalas brancas. Estames subisomórficos, brancos; tecas ca. $2 \mathrm{~mm}$, uniporosas; conectivo espessado no dorso, nos estames ante-pétalos prolongado e curtamente calcarado na base, nos antesépalos com apêndice clavado e glândulas sésseis. Ovário 3-4 locular, esparsamente piloso no ápice; estilete filiforme. Baga sulcada, alaranjada; 2 sementes por lóculo.

Distribuição e habitat: Ocorre em Minas Gerais, Rio de Janeiro, São Paulo, Paraná, Santa Catarina, Rio Grande do Sul e parte da Argentina. Em São Paulo é encontrada em diversas formações florestais.

Material selecionado examinado: Brasil, São Paulo: Assis, 16/XI/1992, Durigan s.n. (UEC 71394); Campos do Jordão, 26/V/1990, Pirani 2593 \& Freire-Fierro (SPF); Juquiá, 25/VI/1941, Kuhlmann \& Kuehn s.n. (SP 45758); Moji Guaçu, 06/X/1982, Martins 14319 (UEC); Praia Grande, 16/V/1992, Kawall 162 (SP); São Bento do Sapucaí, 17/VIII/1994, Tamashiro 532 et al. (UEC); São Paulo, X/1940, Hoehne s.n. (SPF 10652); Sete Barras, 13/II/1995, Leitão Filho et al. 33332 (UEC).

Alguns exemplares de Miconia cinerascens depositados em herbários paulistas estavam identificados como $M$. paulensis Naudin. O exame destes materiais não revelou a presença de ovário ínfero ou folhas lanceoladas de margem inteira, características consideradas diagnósticas para M. paulensis, segundo Cogniaux (1887/ 1888); tratamos estes exemplares como pertencentes a $M$. cinerascens, como sugere Wurdack (1962). 
12. Miconia cinnamomifolia (DC.) Naudin, Ann. Sci. Nat. Bot., ser. 3, 16: 68. 1851; Cremanium cinnamomifolium DC., Prodr. 3: 194. 1828; Miconia candolleana Triana, Trans. Linn. Soc. Bot. 28: 117, 1871, non M. candolleana Naudin, Ann. Sci. Nat. Bot., ser. 3, 16: 244. 1851. Seção Glossocentrum.

Árvores 8-12(-20)m. Ápices dos ramos e folhas jovens recobertos por indumento estrelado-furfuráceo a sublepidoto, posteriormente totalmente glabros, exceto na região dos nós. Folhas com pecíolo 1-2,5cm, com pseudo-estípulas interpeciolares; lâmina $5-12 \times 2-4,5 \mathrm{~cm}$, coriácea, oval a elíptica, base aguda levemente decurrente, ápice agudo curtamente acuminado, margem levemente revoluta e espessada, nervuras acródromas suprabasais; ambas as faces glabras nas folhas maduras. Panículas densas, até $10 \mathrm{~cm}$. Flores pentâmeras; hipanto ca. $1,5 \mathrm{~mm}$; cálice caduco, lacínias internas arredondadas, externas triangulares muito reduzidas; pétalas brancas. Estames subisomórficos, brancos; tecas 1,5-2mm, uniporosas; conectivo dos estames ante-sépalos basalmente alargado e bilobado no dorso, dos ante-pétalos curtamente calcarados no dorso e ventralmente biauriculados. Ovário 3-locular, glabro; estilete abruptamente alargado no ápice. Baga atro-violácea; ca. 10 sementes por lóculo.

Distribuição e habitat: Ocorre desde a Bahia até Santa Catarina. Em São Paulo ocorre em diversas formações florestais.

Material selecionado examinado: Brasil, São Paulo: Atibaia, 15/VIII/1987, Bernacci et al. 21255 (UEC); Cananéia, Ilha do Cardoso, IX/1976, Davis et al. D. 60605 (UEC); Cruzeiro, 05/IX/1995, Goldenberg 64 \& Koch (UEC); Jundiaí, 14/XII/1984, Morellato-Fonzar \& Rodrigues 17792 (UEC); Guarujá, 05/XI/1986, Leitão Filho et al. 18751 (UEC); Pariquera-Açu, 12/II/1995, Sartori et al. 33402 (UEC); São José dos Campos, 12///1986, Silva 1376 \& Capellari (UEC); Ubatuba, 26/XI/1991, Romero et al. 398 (UEC).

Espécie de fácil identificação pelo porte elevado - só comparável, em São Paulo, ao de Miconia cabussu - e pela presença de pseudo-estípulas interpeciolares. Informações nomenclaturais são discutidas por Wurdack (1960) e Howard \& Kellog (1989).

13. Miconia collatata Wurdack, Phytologia 29(2): 146. 1974. Seção Glossocentrum.

Arbustos 2-4m a arvoretas até $6 \mathrm{~m}$. Ramos jovens, pecíolos, eixos das inflorescências e pedicelos esparsamente recobertos por tricomas estrelados a dendríticos, posteriormente glabrescentes. Folhas com pecíolo $0,5-2 \mathrm{~cm}$; lâmina $4-13 \times 1,5-5,5 \mathrm{~cm}$, membranácea, elíptica, oval a oval-lanceolada, base atenuada a levemente decurrente, ápice acuminado a curtamente caudado, margem inteira a repanda, nervuras acródromas basais; ambas as faces das folhas jovens recobertas por tricomas estrelados, depois glabras, à exceção das nervuras na face inferior. Panículas $4-7 \mathrm{~cm}$. Flores pentâmeras; hipanto ca. 1,5mm, glabro; cálice glabro, com verticilo interno membra- 
náceo, sem lobos distintos, lacínias externas triangulares tuberculadas; pétalas brancas. Estames dimórficos; tecas ca. $1 \mathrm{~mm}$, uniporosas; conectivo espessado no dorso, prolongado abaixo das tecas, nos estames ante-pétalos biauriculado ventralmente $\mathrm{e}$ curtamente calcarado no dorso, nos ante-sépalos dorsalmente expandido na base em apêndice caudado amplo. Ovário 3-locular, glabro; estilete filiforme. Baga com 1-2 sementes por lóculo.

Distribuição e habitat: Ocorre em Goiás, Paraná e São Paulo, além de Paraguai e Argentina (Wurdack, 1974). Em São Paulo é encontrada em florestas, ao norte e oeste do Estado.

Material selecionado examinado: Brasil, São Paulo: Mirassol, 12/XI/1962, Camargo \& De Marinis 68 (SP); Moji Guaçu, 15/XI/1978, Ratter 8761 (UEC); Porto-Ferreira, 07/XII/1980, Bernacci 20383 (UEC); Teodoro Sampaio, s.d., Pastore 170 (UEC).

14. Miconia corallina Spring, Flora 20, Beibl. 2: 77. 1837. Seção Glossocentrum.

Arbustos até $3 \mathrm{~m}$. Ramos jovens, pecíolos, eixos das inflorescências, hipanto e cálice recobertos por indumento curtamente estrelado-tomentoso, canescente a ferrugíneo. Folhas com pecíolo 1,5-3cm; lâmina 9-13x6-9cm, coriácea, oval, base arredondada a subcordada, ápice obtuso a agudo, margem inteira a subdenticulada, nervuras acródromas basais; face superior das folhas jovens curtamente estrelado-tomentosa, depois glabra, face inferior densamente recoberta por indumento estrelado-tomentoso, canescente a ferrugíneo. Panículas espiciformes de glomérulos, ca. $15 \mathrm{~cm}$. Flores tetrâmeras; hipanto ca. $1 \mathrm{~mm}$; cálice persistente, lacínias internas repandas a arredondadas, externas triangulares curtas; pétala creme ou branca. Estames isomórficos; anteras atenuadas na base e alargadas no ápice, tecas ca. $1 \mathrm{~mm}$, uniporosas; conectivo inapendiculado. Ovário 1-3 locular, glabro; estilete levemente espessado no ápice. Baga alaranjada; 1-3 sementes, sempre uma por lóculo.

Distribuição e habitat: A espécie ocorre em Minas Gerais e Rio de Janeiro, sendo pouco freqüente em São Paulo. Além do exemplar citado por Cogniaux (1887/1888) em "Mogi", M. corallina só foi coletada uma única vez na Serra da Mantiqueira, a $1400 \mathrm{~m}$ de altitude.

Material examinado: Brasil, São Paulo: Serra da Mantiqueira, estrada para Itajubá, 16/III/1939, Kuhlmann \& Gerht s.n. (SP 4049).

M. corallina é muito semelhante a $M$. castaneaeflora, diferindo principalmente pela textura das folhas e forma das lacínias do cálice.

15. Miconia cubatanensis Hoehne, Anexos Mem. Inst. Butantan, secc. Bot. 1(5): 139140. 1922. Seção Glossocentrum. 
Arvoretas 3-4m. Ramos, pecíolos, eixos das inflorescências, hipanto e cálice densamente recobertos por indumento estrelado a lepidoto, canescente a ocráceo. Folhas com pecíolo 0,5-2,5cm; lâmina 4-13×1-14cm, cartácea, oval-lanceolada, base atenuada a ligeiramente arredondada, ápice acuminado a caudado, margem inteira levemente revoluta, nervuras acródromas basais a suprabasais; face superior glabra, inferior densamente recoberta por indumento estrelado-lepidoto, canescente a ocráceo. Panículas tirsóideas, $3-6 \mathrm{~cm}$. Flores pentâmeras; hipanto ca. $2 \mathrm{~mm}$; cálice caduco, com lacínias externas triangulares e internas inconspícuas; pétalas brancas. Estames dimórficos, brancos; tecas ca. 1,5mm, uniporosas; conectivo espessado no dorso, ventralmente inapendiculado, nos estames ante-sépalos com cálcar basal pronunciado, nos ante-pétalos com cálcar mais curto. Ovário 2-locular, estrelado-tomentoso no ápice; estilete filiforme. Baga atropurpúrea; 2 sementes grandes por lóculo.

Distribuição e habitat: Ocorre em Minas Gerais, São Paulo, Paraná e Santa Catarina. Em São Paulo é encontrada apenas em formações florestais costeiras e na Serra do Mar.

Material selecionado examinado: Brasil, São Paulo: Bertioga, 11/VI/1940, Hoehne s.n. (SP 42720); Cananéia, Ilha do Cardoso, 10/06/1993, Goldenberg 28618 (UEC); Paranapiacaba, 20/IV/1971, Handro 2163 (SPF, UEC); São Paulo, 02/V/1944, Hoehne s.n. (SPF 11441); s.d., Frazão, s.n. (SP 10767); Ubatuba, 17/VI/1985, Semir et al. 17637 (UEC).

16. Miconia depauperata Gardner, J. Bot. (Hooker) 2: 346. 1840. Seção Glossocentrum.

Arbustos ca. $2 \mathrm{~m}$. Ramos jovens, pecíolos, eixos das inflorescências, hipanto e cálice densamente recobertos por indumento estrelado-furfuráceo ocráceo. Folhas com pecíolo 0,8-1,2cm; lâmina 4,5-9,5×1,6-3,5cm, cartácea, elíptico-oblonga, base atenuada, ápice acuminado a caudado, margem inteira, nervuras acródromas basais; face superior das folhas jovens estrelado-furfurácea, depois glabra, face inferior esparsa a moderadamente recoberta por indumento estrelado-furfuráceo, canescente a ocráceo. Panículas ca. $8 \mathrm{~cm}$. Flores pentâmeras; hipanto $2,5 \mathrm{~mm}$; cálice caduco, com lacínias externas triangulares agudas, internas membranáceas e inconspícuas; pétalas brancas. Estames subisomórficos, brancos; tecas ca. $2 \mathrm{~mm}$, uniporosas; conectivo curtamente prolongado abaixo das tecas, espessado no dorso, inapendiculado nos estames ante-pétalos e curtamente calcarado nos ante-sépalos. Ovário 3-locular, glabro; estilete levemente espessado no ápice. Frutos e sementes não vistos.

Distribuição e habitat: Ocorre em Minas Gerais e Rio de Janeiro, sendo representada em São Paulo por um único exemplar, coletado no Jardim Botânico, na Capital. 
Material examinado: Brasil, São Paulo: São Paulo, 06/VI/1932, Hoehne s.n. (SP 29716).

Miconia depauperata é muito próxima de $M$. brasiliensis Triana, não citada para São Paulo por Cogniaux (1887/1888). Provavelmente as duas espécies são sinônimos, uma vez que a principal diferença entre ambas, segundo Cogniaux (1887/ 1888), reside no indumento glabrescente em $M$. depauperata e persistente em $M$. brasiliensis. O material citado por Hoehne (1922) como M. brasiliensis - Frazão s.n. (SP 10767) - pertence a M. cubatanensis.

\section{Miconia discolor DC., Prodr. 3: 184. 1828. Seção Miconia-Seriatiflorae. Fig. Ib}

Arbustos até $3 \mathrm{~m}$. Ramos, pecíolos, brácteas, bractéolas, hipanto e cálice densamente revestidos por indumento estrelado, adpresso, canescente. Folhas com pecíolo 0,5-2cm; lâmina $15-25 \times 5-9 \mathrm{~cm}$, cartácea, oblanceolada a obovada, base longamente atenuada, decurrente no pecíolo, ápice obtuso a curtamente acuminado, com múcron curto, margem crenulada, nervuras acródromas suprabasais e um par basal marginal; face superior glabra, inferior densamente ou raro esparsamente recoberta por indumento estrelado, adpresso e canescente. Panículas de glomérulos, ca. $15 \mathrm{~cm}$; ramos secundários curtos (até $2,5 \mathrm{~cm}$ ) e geralmente 1 glomérulo na extremidade. Flores pentâmeras; hipanto $2 \mathrm{~mm}$; cálice caduco, com lacínias internas truncadas e externas tuberculadas inconspícuas; pétalas brancas. Estames isomórficos, brancos; tecas ca. $3 \mathrm{~mm}$, uniporosas; conectivo levemente espessado no dorso e ventralmente projetado na base em aurículas arredondadas curtas. Ovário 3-locular, glabro; estilete filiforme. Baga atropurpúrea quando madura; sementes pouco numerosas, 2 por lóculo.

Distribuição e habitat: No Brasil, ocorre em Minas Gerais, Rio de Janeiro, São Paulo, Paraná e Santa Catarina. Em São Paulo ocorre em formações de planalto, geralmente em áreas brejosas, matas de galeria ou florestas perturbadas.

Material selecionado examinado: Brasil, São Paulo: Campinas, 22/II/1988, Arruda 20076 (UEC); Limeira, 01/XI/1954, Hoehne s.n. (UEC 65082); Monteiro Lobato, 17/VIII/1994, Tamashiro 518 et al. (UEC); Nazaré Paulista, 25/IX/1991, Meira Neto et al. 792 (UEC); Porto Ferreira, 11/IX/1980, Bertoni 20374(UEC); Rio Claro, 05/V/ 1982, Pagano 370 (UEC); Taquaras, 14/VI/1995, Tamashiro 1228 et al. (UEC); Vinhedo, 23/IX/1977, Semir et al. 65534 (UEC).

Wurdack (1962) sugere que esta espécie deva ser incluída na seção Glossocentrum (Crueger) Triana.

18. Miconia dodecandra (Desr.) Cogn., in Mart. Fl. Bras. 14(4): 243. 1887. Melastoma dodecandra Desr. in Lam. Encycl. Méth. Bot. 4: 46. 1797. Seção Tamonea. Fig.2b 
Árvores 3,5-10m. Ramos jovens, pecíolos, eixos das inflorescências, brácteas, bractéolas, hipanto e cálice densamente recobertos por indumento estrelado-penicelado a dendrítico. Folhas com pecíolo 2,5-8,5cm; lâmina 9,5-20x4-8,5cm, cartácea, elíptico-lanceolada, base arredondada a atenuada, ápice agudo a acuminado, margem sinuosa, nervuras acródromas basais; face superior glabra, inferior densamente recoberta por tricomas estrelado-penicelados. Panículas $7-15 \mathrm{~cm}$. Flores hexâmeras e pentâmeras; brácteas côncavas, amplas, $0,5 \mathrm{~cm}$ compr.; hipanto $4-6 \mathrm{~mm}$; cálice persistente, com lacínias internas e externas fundidas, repandas; pétalas brancas a rosadas. Estames isomórficos; tecas 7-8mm, uniporosas; conectivo giboso, espessado a partir do terço inferior da teca, ventralmente projetado em aurículas contínuas. Ovário 4-5 locular, furfuráceo no ápice; estilete estrelado a furfuráceo na metade inferior e abruptamente alargado no ápice. Baga cinérea; sementes pequenas e numerosas por lóculo.

Distribuição e habitat: Espécie amplamente distribuída desde o México até o Brasil, onde ocorre na Bahia, Distrito Federal, Rio de Janeiro, São Paulo e Paraná. Em São Paulo é característica de formações florestais costeiras.

Material selecionado examinado: Brasil, São Paulo: Bertioga, 04/XI/1986, Tamashiro et al. 18723 (UEC); Cananéia, 20/V/1988, Leitão Filho et al. 20343 (UEC); Cubatão, 03/II/1988, Leitão Filho et al. 20780 (UEC); Iguape, 10/XII/1981, Stubblebine et al. 13212 (UEC); Pariquera-Açu, 11///1995, Bernacci 1092 et al. (UEC); Peruíbe, 17/VIII/1994, Stehmann 1473 \& Sobral (UEC); Ubatuba, 16/VI/1986, Taroda et al. 17638 (UEC).

Miconia dodecandra tem sido distinguida de M. mirabilis (Aubl.) L. O. Williams pela presença de indumento no hipanto e cálice. Esta diferença parece insuficiente para separar espécies, principalmente porque ambas tem o mesmo habitat e distribuição geográfica.

19. Miconia doriana Cogn. in Mart., Fl. bras. 14(4): 376. 1887. Seção Glossocentrum.

Arbustos a arvoretas ca. $2 \mathrm{~m}$. Ramos, eixos das inflorescências, hipanto e cálice esparsamente estrelado-furfuráceos, posteriormente glabros. Folhas com pecíolo 0,5$0,8 \mathrm{~mm}$; lâmina 3,5-11 x11-3,5cm, membranácea, oblongo-lanceolada, base aguda a atenuada, ápice caudado, margem inteira a curtamente crenada-denticulada, nervuras acródromas suprabasais, na face inferior unidas à base da nervura central por membrana; face superior glabra, inferior glabra ou raro esparsamente recoberta por indumento estrelado-furfuráceo. Panículas ca. $7 \mathrm{~cm}$, piramidais, paucifloras; bractéolas caducas. Flores pentâmeras; pedicelo de $3-7 \mathrm{~mm}$; hipanto ca. $1,5 \mathrm{~mm}$; cálice caduco, com lacínias internas membranáceas, triangulares, ápice arredondado, externas triangulares; pétalas brancas. Estames 12 ou mais, subisomórficos, brancos; tecas ca. 1,5mm, uniporosas; conectivo ligeiramente prolongado abaixo das tecas, curtamente calcara- 
do no dorso. Ovário 2-3 locular, glabro; estilete levemente espessado no ápice. Baga com 1 semente por lóculo.

Distribuição e habitat: Ocorre no Espírito Santo, Rio de Janeiro, São Paulo e Santa Catarina. Em São Paulo ocorre em formações florestais em altitudes elevadas.

Material selecionado examinado: Brasil, São Paulo: Atibaia, s.d., Novaes s.n. (SP 11900); São Paulo, 07/X/1905, Usteri s.n. (SP 11901); 04/I/1921, Hoehne s.n. (SP 5986).

Espécie muito próxima de Miconia paniculata (Mart. \& Schrank ex DC.) Naudin, da qual difere pelo número de estames e bractéolas caducas. No exemplar Hoehne s.n. (SP 5986), as lacínias do cálice são longamente triangulares, distintas das observadas em exemplares de $M$. doriana provenientes de outros Estados.

20. Miconia elegans Cogn. in Mart., Fl. bras. 14(4): 312. 1887. Seção MiconiaPaniculares.

Arbustos ou árvores até $4 \mathrm{~m}$. Ramos, pecíolos, eixos das inflorescências, hipanto e cálice moderado a esparsamente recobertos por tricomas peltado-estrelados. Folhas com pecíolo $0,5-1,5 \mathrm{~cm}$; lâmina $15-30 \times 6-12 \mathrm{~cm}$, subcoriácea, oval-elíptica a elípticolanceolada, base arredondada a cuneada, ápice acuminado, margem às vezes repanda, nervuras acródromas suprabasais; face superior das folhas jovens com tricomas estrelados, depois glabras, face inferior esparsamente recoberta por tricomas estrelados curtos. Panículas até $15 \mathrm{~cm}$. Flores pentâmeras; hipanto ca. $4 \mathrm{~mm}$; cálice caduco, com lacínias internas triangulares, externas tuberculadas agudas. Estames isomórficos, brancos; tecas ca. $3 \mathrm{~mm}$, corrugadas, uniporosas; conectivo pouco prolongado abaixo das tecas e levemente projetado no dorso. Ovário 3-locular, glabro; estilete levemente espessado no ápice. Baga e sementes não vistas.

Distribuição e habitat: Coletada em cerrados na Bahia, Distrito Federal, Minas Gerais e São Paulo.

Material examinado: Brasil, São Paulo: Itirapina, VIII/1985, Cesar \& Federsen Jr. 611 (UEC).

Comentários em M. prasina (Sw.) DC.

21. Miconia fallax DC., Prodr. 3: 181. 1828. Seção Miconia-Seriatiflorae. Fig.1c

Arbustos até $2 \mathrm{~m}$. Ramos, pecíolos, brácteas, bractéolas, hipanto e cálice densamente revestidos por indumento estrelado, canescente. Folhas sésseis a subsésseis; lâmina 9-13 $\times 4,5-6,5 \mathrm{~cm}$, subcoriácea, ovalada, base arredondada a cordada, ápice 
arredondado a agudo, nunca acuminado, com múcron curto, margem levemente crenada e revoluta, nervuras acródromas basais; face superior glabra, inferior densamente recoberta por indumento estrelado canescente. Panículas escorpióides, ca. $15 \mathrm{~cm}$. Flores pentâmeras; hipanto $3 \mathrm{~mm}$; cálice persistente, com lacínias internas e externas fundidas, triangulares e agudas; pétalas brancas, margem ciliado-glandulosa. Estames isomórficos, amarelos; tecas ca. $4 \mathrm{~mm}$, uniporosas; conectivo espessado no dorso e levemente calcarado na base. Ovário 3-locular, glabro; estilete levemente espessado no ápice. Baga atropurpúrea quando madura; sementes numerosas, ca. 15 por lóculo.

Distribuição e habitat: Ocorre na Venezuela, Guiana e Brasil, nos Estados de Roraima, Pará, Bahia, Minas Gerais e São Paulo. Neste Estado é encontrada em cerrado.

Material selecionado examinado: Brasil, São Paulo: Águas de Santa Bárbara, 19/VIII/ 1989, Meira Neto 437(UEC); Altinópolis, 17/IX/1977, Leitão Filho \& Martins 5934 (UEC); Botucatu, 21///1986, Bicudo et al. 306 (UEC); Corumbataí, 10/X/1982, Pagano 14717 (UEC); Indaiatuba, 08/IX/1956, Grotta s.n. (UEC 65090); Itirapina, 03/IX/1980, Gianotti 12312 (UEC); Moji Guaçu, 09/X/1982, Martins 14303 (UEC); Santa Rita do Passa Quatro, I/1986, Castro 19724 (UEC); São José dos Campos, 11 / IX/1962, Mimura 541 (SP).

A distinção entre $M$. fallax e $M$. stenostachya não é muito clara. Wurdack (1973) considera $M$. fallax como sendo apenas uma variedade de $M$. stenostachya. As diferenças entre ambas se baseiam na morfologia das folhas, visto que possuem características florais muito semelhantes, como a presença de tricomas glandulares nas margens das pétalas e estames cujos filetes, com o tempo, mudam de cor do amarelo para o alaranjado e depois vermelho nas flores mais velhas.

22.Miconia ferruginata DC. Prodr., 3: 181. 1828. Seção Miconia-Seriatiflorae. Fig.1d

Arbustos até $2 \mathrm{~m}$; ramos muito engrossados. Ramos, brácteas, bractéolas, hipanto e cálice densamente revestidos por tricomas estrelados ocráceos. Folhas com pecíolo 1-3cm; lâmina 10-23x7-10cm, coriácea, oblonga, elíptica ou lanceolada, base arredondada a subcordada, ápice obtuso agudo ou levemente acuminado, margem sinuosa, nervuras acródromas basais; face superior das folhas jovens com tricomas estrelados ocráceos, depois glabra, face inferior densamente recoberta por indumento semelhante. Panículas escorpióides, longas, até $35 \mathrm{~cm}$; brácteas e bractéolas longas, caducas. Flores pentâmeras; hipanto ca. $4 \mathrm{~mm}$; cálice persistente, com lacínias internas repandas e externas triangulares tuberculadas; pétalas brancas. Estames subisomórficos, amarelos; tecas ca. $3 \mathrm{~mm}$, uniporosas; conectivo muito espessado no dorso, bastante prolongado abaixo das tecas, dorsalmente expandido na base e ventralmente projetado em apêndices obtusos. Ovário 3-locular, glabro, estilete levemente espessado no ápice. Baga atropurpúrea quando madura; sementes numerosas, ca. 15 por lóculo. 
Distribuição e habitat: Ocorre apenas no Brasil, em Mato Grosso, Goiás, Distrito Federal, Minas Gerais, Bahia e São Paulo. Neste Estado é encontrada em algumas áreas de vegetação de cerrado.

Material examinado: Brasil, São Paulo: São José dos Campos, 12/X/1962, Mimura 559 (SP); Itu, 07/I/1987, Souza \& Silva 25382 (UEC); 18/IV/1987, Souza 25353 (UEC).

23. Miconia hispida Cogn. in Mart., Fl. bras. 14(4): 392-396. 1887. Seção Chaenanthera.

Arbustos ou arvoretas até $4 \mathrm{~m}$. Ramos jovens, pecíolos, eixos das inflorescências, bractéolas, hipanto e cálice moderada a densamente recobertos por tricomas híspidos, mesclados com indumento estrelado furfuráceo. Folhas com pecíolo 0,4$1 \mathrm{~cm}$; lâmina 6-12 x1,5-3,5cm, cartácea, oval-lanceolada, base arredondada a aguda, ápice acuminado, margem serreada, nervuras acródromas suprabasais; face superior híspida, depois glabra, face inferior esparsa a moderadamente recoberta por tricomas híspidos, mesclados com tricomas estrelado-furfuráceos esparsos, principalmente sobre as nervuras. Panículas $4-7 \mathrm{~cm}$; bractéolas $2-4 \mathrm{~mm}$, caducas. Flores pentâmeras; hipanto ca. $2 \mathrm{~mm}$; cálice caduco, com lacínias internas membranáceas, arredondadas e com margem ciliolada, externas constituídas por dentículos; pétalas brancas. Estames isomórficos; tecas ca. $2 \mathrm{~mm}$, rimosas quase até a base, conectivo prolongado abaixo das tecas, não apendiculado. Ovário trilocular, glabro; estilete levemente espessado no ápice. Baga com uma semente por lóculo.

Distribuição e habitat: Ocorre na Bahia, Minas Gerais e São Paulo, em formações florestais de altitudes elevadas.

Material selecionado examinado: Brasil, São Paulo: Amparo, 07/IV/1943, Kuhlmann 640 (UEC); Jaú, 25/IX/1956, Handro 633 (SP); Jundiaí, 28/V/1995, Goldenberg 40 (UEC); IX/1995, Goldenberg 93 (UEC); Rio Claro, 07/VI/1888, Löfgren 606 (C).

24. Miconia holosericea (L.) DC., Prodr. 3: 181. 1828. Melastoma holosericea L., Sp. Pl.: 390. 1753. Seção Jucunda.

Arbustos de $2 \mathrm{~m}$ a árvores 6-10m. Ramos, pecíolos, eixos das inflorescências, hipanto e cálice densamente recobertos por indumento estrelado a dentrítico-estrelado. Folhas com pecíolo 1,5-3,5 mm; lâmina 13-23×6-9,5cm, subcoriácea, oval-elíptica, base atenuada a arredondada, ápice agudo a curto-acuminado, margem inteira a levemente ondulada, nervuras acródromas basais ou curtamente suprabasais; face superior glabra, exceto sobre as nervuras, inferior densamente vilosa. Panículas paucifloras, 3-8cm. Flores hexâmeras; brácteas 3-5 mm, caducas; hipanto ca. $5 \mathrm{~mm}$; cálice caduco, 
com lacínias externas largamente triangulares, internas membranáceas e truncadas; pétalas brancas. Estames subisomórficos, roxos; tecas ca. $7 \mathrm{~mm}$, uniporosas; conectivo dorsalmente espessado a partir do terço inferior da teca, ventralmente bilobado. Ovário 4-locular, esparsamente glandular-pubérulo no ápice; estilete levemente espessado no ápice. Baga subglobosa; sementes não vistas.

Distribuição e habitat: Ocorre desde o sul do México até a Bolívia e sudeste do Brasil. Em São Paulo esta espécie foi encontrada apenas em formações costeiras.

Material selecionado examinado: Brasil, São Paulo: Ubatuba: 25/VI/1991, Romero et al. 325 (UEC); 02/XII/1988, Garcia 180 et al. (UEC).

25. Miconia hyemalis A.St.-Hil. \& Naudin ex Naudin, Ann. Sci. Nat. Bot., ser. 3, 16: 142. 1851. Seção Cremanium.

Arbustos 1,5-3m. Ramos jovens, pecíolos e eixos das inflorescências densamente recobertos por indumento dendrítico-estrelados, cinéreos a ocráceos; hipanto e cálice com indumento estrelado-pubérulo. Folhas com pecíolo $0,5-1,5 \mathrm{~cm}$; lâmina $5-13 \times 2-4,5 \mathrm{~cm}$, subcoriácea, oval-elíptica a oval-lanceolada, base arredondada a subcordada, ápice agudo a curtamente acuminado, margem conspicuamente denteada, nervuras acródromas basais a curtamente suprabasais; face superior das folhas jovens estrelado-pubérula, face inferior densamente recoberta por indumento dendríticoestrelado. Panículas congestas, $3-6 \mathrm{~cm}$. Flores pentâmeras; hipanto ca. $3 \mathrm{~mm}$; cálice caduco, com lacínias internas truncadas, externas curtamente deltóides; pétalas creme, papiloso-pubérulas no ápice. Estames subisomórficos, creme; tecas ca. $2 \mathrm{~mm}$, curtamente obovadas, biporosas; conectivo dos estames ante-sépalos levemente alargados na base, estames ante-pétalos calcarados no dorso. Ovário 3-locular, pubérulo no ápice; estilete filiforme. Frutos e sementes não vistos.

Distribuição e habitat: Ocorre desde São Paulo até o Rio Grande do Sul e Uruguai. Em São Paulo é encontrada em cerrados e vegetação arbustiva, em locais de altitudes elevadas.

Material selecionado examinado: Brasil, São Paulo: Campos do Jordão, XII/1988, Valeriano s.n. (UEC 73573); Itapeva, 15/VI/1995, Tamashiro 1313 et al. (UEC); São Bento do Sapucaí, 13/IV/1995, Tamashiro et al. (UEC); São Paulo, 28./IX/1951, Hoehne s.n. (SPF 13806); Ubatuba, 20/III/1973, Sousa s.n. (IAC 22842).

26. Miconia hymenonervia (Raddi) Cogn. in Mart., Fl. bras. 14(4): 399. 1888. Melastoma hymenonervia Raddi, Mem. Soc. Ital. Mod. 20: 135. 1829. Seção Chaenanthera.

Arbustos $1,5 \mathrm{~m}$ a arvoretas $7 \mathrm{~m}$. Ramos, pecíolos, eixos das inflorescências, 
hipanto e cálice esparsamente recobertos por indumento estrelado-furfuráceo, posteriormente glabros. Folhas com pecíolo $0,5-1,5 \mathrm{~cm}$; lâmina $4-15 \times 1,5-5 \mathrm{~cm}$, membranácea a cartácea, oblongo-elíptica a oboval, base atenuada, ápice caudado, margem inteira a denticulada, nervuras subalternas acródromas curtamente suprabasais, na face inferior unidas à base da nervura central por membrana; ambas as faces das folhas jovens esparsamente estrelado-furfuráceas, depois glabras, à exceção das nervuras na face inferior. Panículas $6-16 \mathrm{~cm}$. Flores tetrâmeras ou pentâmeras; hipanto ca. $2 \mathrm{~mm}$; cálice caduco, lacínias internas triangulares agudas, externas constituídas por dentículos reduzidos, menores que as internas; pétalas brancas. Estames isomórficos, brancos; tecas ca. $1 \mathrm{~mm}$, rimosas até a base; conectivo prolongado abaixo das tecas, não apendiculado. Ovário 3-locular, glabro; estilete levemente espessado no ápice. Baga com uma semente por lóculo.

Distribuição e habitat: Ocorre em Minas Gerais, Espírito Santo, Rio de Janeiro, São Paulo, Paraná e Santa Catarina, além de Paraguai e Argentina. Em São Paulo é encontrada em diversas formações florestais, mas nunca ao nível do mar.

Material selecionado examinado: Brasil, São Paulo: Águas da Prata, 23/III/1994, Martins et al. 31406 (UEC); Amparo, 08/IV/1943, Kuhlmann 659 (SP); Atibaia, 04/ V/1990, Bernacci et al. 21092 (UEC); Brotas, 08/IV/1986, Sales \& Joly 76 (UEC); Buri, 05/IV/1985, Franceschinelli 17124 (UEC); Cafelândia, 15/IX/1938, Hashimoto 19 (SP); Campinas, V/1918, Campos Novaes 1999(SP); Campos do Jordão, 20/VI/ 1940, Hasmimoto 208 (SP); Igaratá, 03/VIII/1949, Kuhlmann 1949 (SP); Itirapina, 16/V/1927, Hoehne s.n. (SP 20335); Joanópolis, 30/IV/1946, Kuhlmann 1347 (SP); Jundiaí, 25/III/1995, Goldenberg 38 (UEC); Moji Guaçu, 24/IX/1980, Forero 8445 et al. (SP); Monteiro Lobato, 17/VIII/1994, Tamashiro 519 et al. (UEC); Paraibuna, 25/III/1984, Shepherd \& Tamashiro 15820 (UEC); Piquete, 14/II/1994, Arbocz 131 (UEC); Ribeirão Preto, 01/IV/1920, Gehrt s.n. (SP 4015); Rio Claro, 30/III/1979, Pagano II8 (HRCB); Santo Antonio de Posse, 16/IV/1994, Arbocz 308 (UEC); São Paulo, 22/V/1917, Hoehne s.n. (SP 145); Serra Negra, 03/VI/1927, Hoehne s.n. (SP 20652); Ubatuba, 22/VIII/1976, Davis et al. 59939 (UEC); Valinhos, s.d., Campos Novaes s.n. (SP 15862); Vinhedo, 25/VIII/1983, Chiea 355 (SP).

A distinção entre Miconia hymenonervia, $M$. inaequidens (DC.) Naudin e $M$. pusilliflora (DC.) Triana é bastante discutível, uma vez que estas espécies apresentam sobreposição das características anteriormente utilizadas na sua separação, como margem das folhas inteiras ou serreadas e número das peças florais (Baumgratz 1984; Cogniaux 1887/1888; Wurdack 1962). Estamos considerando o material coletado em São Paulo como pertencente a $M$. hymenonervia por ser este epíteto o mais antigo. Estas espécies deverão ser sinonimizadas quando os tipos forem examinados. $\mathrm{O}$ material citado por Hoehne (1922) como M. elaeodendron (DC.) Naudin - Hoehne s.n. (SP 145) - pertence a M. hymenonervia. 
27. Miconia ibaguensis (Bonpl.) Triana, Trans. Linn. Soc. London 28: 110. 1871. Melastoma ibaguensis Bonpl. in Humb. \& Bonpl. Monogr., Melast. 1: 105. 1815. Seção Miconia-Paniculares.

Fig. 1k

Arbustos ca. $2 \mathrm{~m}$, raramente arvoretas até $4 \mathrm{~m}$. Ramos, pecíolos, eixos das inflorescências, hipanto e cálice moderada a densamente revestidos por indumento estrelado-furfuráceo ocráceo a ferrugíneo, mesclado com tricomas setulosos a híspidos. Folhas com pecíolo ca. $0,5 \mathrm{~cm}$; lâmina $5-17 \times 2-6 \mathrm{~cm}$, membranácea, levemente bulada, lanceolada a oval-lanceolada, base obtusa a arredondada, ápice acuminado a agudo, margem curtamente serreado-ciliada, nervuras acródromas suprabasais; face superior das folhas jovens esparsamente furfuráceo-setulosa, posteriormente glabrescente, face inferior moderadamente recoberta por tricomas setulosos, sendo as nervuras recobertas por tricomas setulosos mesclados com tricomas estrelados. Panículas 3$8 \mathrm{~cm}$. Flores pentâmeras; hipanto 2-3mm; cálice com lacínias internas membranáceas, deltóides, externas subuladas, curtas; pétalas brancas. Estames subisomórficos, amarelos; tecas ca. $3 \mathrm{~mm}$, corrugadas, uniporosas; conectivo espessado no dorso e giboso na inserção com o filete, ventralmente biauriculado na base. Ovário 3-locular, glabro; estilete abruptamente alargado no ápice. Baga não vista.

Distribuição e habitat: Ocorre desde o sul do México até o sudeste do Brasil e Bolívia. Em São Paulo é encontrada em vegetação secundária, em locais úmidos.

Material selecionado examinado: Brasil, São Paulo: Atibaia, 07/X/1990, Pismel s.n. (UEC 61340); Campo Alegre, 24/VIII/1990, Toledo \& Gerht s.n. (SP); Casa Branca, 4/IX/1978, Toledo Filho 9887 (UEC); Eldorado, 9/IX/1990, Davis et al. D.60852 (UEC); Porto Ferreira, 11/IX/1980, Bertoni 20375 (UEC).

28. Miconia inconspicua Miq., Linnaea 22: 542. 1849. Seção Cremanium. Fig.2h

Árvores 5-8m. Ramos jovens, pecíolos, bractéolas, hipanto e cálice densa a moderadamente recobertos por indumento estrelado canescente a ocráceo. Folhas com pecíolo 1-2,5cm; lâmina 6-13×1,5-4,5, cartácea, oblongo-lanceolada a ovallanceolada, base obtusa, ápice acuminado ca. $1,5 \mathrm{~cm}$, margem crenado-denteada, nervuras acródromas basais; face superior das folhas jovens com tricomas estrelados, depois glabra, face inferior moderada a densamente recoberta por indumento estrelado canescente. Panículas piramidais, $4-10 \mathrm{~cm}$. Flores pentâmeras; hipanto ca. $2 \mathrm{~mm}$; cálice persistente, com lacínias internas arredondadas e externas mais curtas, tuberculadas; pétalas brancas. Estames subisomórficos, brancos; tecas ca. $1 \mathrm{~mm}$, biporosas; conectivo espessado no dorso, basalmente expandido, nos estames ante-pétalos com aurículas ventrais curtas e pequeno cálcar dorsal, nos ante-sépalos ampla e basalmente expandido no dorso e ventralmente projetado em aurículas largas, contínuo da região ventral à dorsal. Ovário 3-locular, furfuráceo no ápice; estilete levemente espessado no ápice. Baga com poucas sementes por lóculo. 
Distribuição e habitat: Ocorre em Minas Gerais, Rio de Janeiro, São Paulo e Catarina. Em São Paulo ocorre em diversas formações florestais.

Material selecionado examinado: Brasil, São Paulo: Cruzeiro, 05/IV/1995, Goldenberg 62 \& Koch (UEC); Jacupiranga, 14/II/1995, Arbocz et al. 33444 (UEC); Joanópolis, 16/VIII/1994, Tamashiro 485 et al. (UEC); Pariquera-Açu, 12/I/1995, Bernacci et al. 1151 (UEC); São Paulo, 30/IX/1958, Handro 816 (SP); São José dos Campos, 10/IX/1985, Silva 1227 \& Martins s.n. (UEC); Ubatuba, 15/IX/1970, Leitão Filho 1042 (IAC).

Alguns exemplares coletados em São Paulo têm sido identificados como $M$. conferta Cogn. Segundo Cogniaux (1887/1888), M. inconspicua difere desta espécie por apresentar estames oblongos exsertos. Como as duas espécies são indistinguíveis e o binômio Miconia inconspicua é mais antigo, decidimos adotar este nome para o material de São Paulo, antecipando uma provável sinonimização.

29. Miconia jucunda (Schrank et Mart. ex DC.) Triana, Trans. Linn. Soc. Bot. 28: 101. 1871. Osbeckia jucunda DC., Prodr. 3: 139. 1828. Seção Jucunda. Fig.2a

Arbustos a arvoretas 1,5-4m. Ramos jovens, pecíolos, eixos das inflorescências e hipanto esparsamente recobertos por indumento furfuráceo-estrelado com alguns tricomas dendríticos. Folhas com pecíolo $0,5-2,5 \mathrm{~cm}$; lâmina $5-13,5 \times 1,6-5 \mathrm{~cm}$, cartácea, elíptica a lanceolada, base pouco arredondada a atenuada, ápice agudo a acuminado, margem inteira ou ocasionalmente serreada, nervuras acródromas basais; face superior glabra, inferior esparsamente recoberta por indumento estrelado-furfuráceo ou glabra. Panículas até $16 \mathrm{~cm}$. Flores pentâmeras; brácteas ca. $1 \mathrm{~cm}$, linear-oblongas, avermelhadas, caducas; hipanto ca. $3 \mathrm{~mm}$; cálice caduco, com lacínias internas membranáceas, externas triangulares, agudas, com o mesmo comprimento ou mais curtas; pétalas brancas a rosadas. Estames dimórficos, amarelos; tecas 5,5 ou $7 \mathrm{~mm}$, uniporosas; conectivo dos estames ante-sépalos dorsalmente expandido na base, dos antepétalos inconspicuamente calcarado no dorso e ventralmente projetado em aurículas curtas. Ovário 3-locular, glabro; estilete filiforme. Baga avermelhada; sementes numerosas.

Distribuição e habitat: Ocorre nos Estados da Bahia, Minas Gerais, Rio de Janeiro, São Paulo, Paraná e Santa Catarina. Em São Paulo é encontrada em locais úmidos e sombreados, principalmente em matas ciliares.

Material selecionado examinado: Brasil, São Paulo: Atibaia, 18/XI/1968, Aranha 44 (IAC); Brotas, 16/XII/1986, Salis \& Lieberg 69 (UEC); Campinas, 10/XII/1988, Vicentin s.n. (UEC 61323); Iguape, XII/1911, Brade 6073 (SP); Luiz Antônio, 19/ XII/1987, Pirani 2053 et al. (SPF, UEC); Mogi das Cruzes, 19/IV/1921, Gerht s.n. 
(SP 5499); Moji Guaçu, 23/IX/1980, Barros 439 (SP); Porto Ferreira, 10/III/1980, Bertoni 20380 (UEC); São Paulo, 29/XII/1917, Hoehne s.n. (SP 1168).

30. Miconia langsdorffii Cogn. in Mart., Fl. bras. 14(4): 232. 1887. Seção Jucunda .

Arbustos ou arvoretas 1-3m. Ramos jovens, pecíolos, eixos das inflorescências e hipanto esparsamente furfuráceos a subglabrescentes. Folhas com pecíolo 0,2-0,8cm; lâmina 2-8x0,5-2 cm, membranácea, lanceolada a oblongo-lanceolada, base atenuada a arredondada, ápice acuminado, margem levemente repanda, nervuras acródromas suprabasais ou ocasionalmente basais; face superior glabra, inferior furfurácea apenas sobre as nervuras. Panículas $4-10 \mathrm{~cm}$. Flores pentâmeras; hipanto 2,5-3 $\mathrm{mm}$; cálice caduco, com verticilo interno truncado e lacínias externas longas, subuladas; pétalas brancas. Estames dimórficos, amarelos; filetes esparsamente glandulosos; tecas 4 ou $5 \mathrm{~mm}$, uniporosas; conectivo nos estames ante-sépalos ligeiramente prolongado no dorso, amplamente expandido na base e com aurículas ventrais curtas; nos ante-pétalos, conectivo não expandido no dorso e com aurículas ventrais reduzidas. Ovário 3-locular, glabro; estilete filiforme, encurvado. Baga atropurpúrea; sementes ca. 8 por lóculo.

Distribuição e habitat: Encontrada apenas em Minas Gerais, São Paulo e Paraná, em cerrados e matas de planalto.

Material selecionado examinado: Brasil, São Paulo: Águas da Prata, 21/III/1994, Martins et al. 31465 (UEC); Águas de Santa Bárbara, 22/II/1990, Meira-Neto 522 (UEC); Anhembi, 15/XII/1981, Cesar s.n. (UEC 053886); Bauru, 6/VII/1992, Azevedo \& Koch 515 (UEC); Campinas, 04/XII/1938, Zagatto \& Vetorato s.n. (IAC 3074); Espírito Santo do Pinhal, 28/XI/1897, Novaes 53 (IAC); Iaras, 13/VI/1995, Tamashiro 1149 et al. (UEC); Itirapina, 10/VIII/1992, Goldenberg 28492 (UEC); Lençóis Paulista, 12/VI/1995, Tamashiro 1066 et al. (UEC); Limeira, 10/XI/1951, Hoehne s.n. (UEC 69425); Moji Guaçu, 19/XI/1980, Mantovani 1351 (SP, UEC); Mogi Mirim, 19/X/1983, Nucci \& Rodrigues 15097 (UEC); Pindorama, 07/XI/1938, Mendes s.n. (ESA 2639); Rio Claro, 10/XI/1982, Pagano 435 (UEC); São Carlos, 08/ XI/1993, Stehmann 1396 \& Sobral (UEC).

31. Miconia latecrenata (DC.) Naudin, Ann. Sci. Nat. Bot., ser. 3, 16: 239. 1851. Cremanium latecrenatum DC., Prodr. 3: 194. 1828. Seção Chaenanthera. Fig.2e

Arbustos a arvoretas 2-4m. Ramos, pecíolos, eixos das inflorescências, hipanto e cálice esparsa a moderadamente recobertos por indumento estrelado-furfuráceo. Folhas com pecíolo $0,5-1,5 \mathrm{~cm}$; lâmina $7-19 \times 2-7,5 \mathrm{~cm}$, membranácea, elíptico-lanceolada a oval-lanceolada, base atenuada raramente arredondada, ápice agudo a acuminado, margem repanda a crenada, nervuras acródromas basais; face superior das folhas jovens estrelado-furfurácea, depois glabra; face inferior esparsamente estrela- 
do-furfurácea ou glabra. Panículas terminais com 7-12cm e pseudo-laterais com 2,5$7 \mathrm{~cm}$. Flores pentâmeras; hipanto 1-1,5mm; cálice caduco, com lacínias internas largamente triangulares, externas obsoletas; pétalas brancas. Estames subisomórficos, brancos; tecas 1-1,5 mm, com poro muito amplo e inclinado (à semelhança de uma rima), atingindo ca. metade do seu comprimento; conectivo basalmente prolongado em cálcar curto, arredondado, curtamente bilobado na face ventral. Ovário 3-locular, ápice esparsamente estrelado; estilete levemente espessado no ápice subclavado. Baga atropurpúrea; sementes 3-6 por lóculo.

Distribuição e habitat: Ocorre desde o Piauí até o Rio Grande do Sul. Em São Paulo ocorre em diversas formações florestais.

Material selecionado examinado: Brasil, São Paulo: Anhembi, 08/VIII/1979, Assumpção s.n. (UEC 21047); Atibaia, 18/IV/1988, Bernacci et al. 21463 (UEC); Bertioga, 30/IX/1983, Custódio Filho 1632 (SP); Cubatão, 03/II/1988, Leitão Filho et al. 20788(UEC); Iguape, 06/IX/1976, Davis 60572 et al. (UEC); Jundiaí, 25/V/1994, Semir \& Stehman 31535 (UEC); Juquiá, 20/VI/1981, Vasconcelos et al. 12597 (UEC); Manduri, 13/VI/1995, Tamashiro 1163 et al. (UEC); Santo André, 31/08/1990, Meira Neto 23540 (UEC); São Miguel Arcanjo, 03/VII/1991, Moraes 464 (UEC); São Paulo, 25/IX/1945, Hoehne s.n. (SPF 11840); Taquaras, 14/VI/1995, Tamashiro 1226 et al. (UEC); Ubatuba, 14/IV/1991, Romero et al. 285 (UEC).

A posição taxonômica seccional de Miconia latecrenata é discutível. A deiscência das anteras, se considerada como rima curta, corrobora sua inclusão na seção Chaenanthera Naudin, segundo Cogniaux (1887/1888). No entanto, se considerarmos a antera dotada de poro muito amplo, poderíamos acomodá-la em Glossocentrum, já que apresenta cálcar dorsal. Baumgratz (1984) questiona também a inclusão em Chaenanthera de M. sellowiana Naudin e M. urophylla DC.

32. Miconia lepidota Schrank et Mart. ex DC., Prodr. 3: 180. 1828. Seção MiconiaSeriatiflorae.

Árvores 8-15m. Ramos, pecíolos, eixos das inflorescências, hipanto e cálice completamente recobertos por indumento lepidoto-estrelado canescente a ocráceo. Folhas com pecíolo 1,5-3cm; lâmina 7-22×3,5-11 cm, cartácea, oval-elíptica a oblongo-elíptica, base atenuada, ápice agudo a abruptamente acuminado, margem inteira levemente sinuosa, nervuras acródromas basais; face superior das folhas jovens lepidoto-furfurácea, posteriormente glabra, face inferior moderada a densamente recoberta por indumento lepidoto-estrelado canescente. Panículas escorpióides, 9$19 \mathrm{~cm}$; bractéolas caducas. Flores pentâmeras; hipanto ca. $2 \mathrm{~mm}$; cálice persistente, com verticilo interno repando, externo formado por dentículos muito reduzidos; pétalas brancas, margem esparsamente ciliada. Estames dimórficos, brancos; tecas $2.5 \mathrm{~mm}$ ou $1,5 \mathrm{~mm}$, uniporosas; conectivo dos estames ante-sépalos bastante espessado 
e inapendiculado no dorso, ventralmente biauriculado, nos estames ante-pétalos com pequena projeção dorsal. Ovário 4-locular, glabro; estilete abruptamente alargado no ápice. Baga com 2-6 sementes por lóculo.

Distribuição e habitat: Ocorre na Venezuela, Guianas e Brasil, na bacia Amazônica, Minas Gerais, Espírito Santo e São Paulo. Neste Estado ocorre em formações florestais de planalto.

Material selecionado examinado: Brasil, São Paulo: Anhembi, 13/V/1981, Cesar s.n. (UEC 53888); 08/VIII/1979, Assumpção s.n. (UEC 21049); Campinas, V/1989, Leitão Filho \& Morellato 22931 (UEC); Guaratinguetá, 5/IV/1994, Arbocz 270 (UEC), Manduri, 13/VI/1995, Tamashiro et al. s.n. (UEC); Monte Alegre do Sul, 20/VII/1949, Kuhlmann 1796 (SP); São José do Barreiro, 30/V/1958, Kuhlmann 4386 (SP).

33. Miconia ligustroides (DC.) Naudin, Ann. Sci. Nat. Bot., ser. 3, 16: 167. 1851. Cremanium ligustroides DC., Prodr. 3: 194. 1828. Seção Glossocentrum. Fig.2c

Arbustos 1-4m até árvores ca. 8m. Ramos, pecíolos, eixos das inflorescências, hipanto e cálice moderado a densamente recobertos por indumento estrelado-furfuráceo, posteriormente glabrescentes a glabros. Folhas com pecíolo 0,2-1 mm; lâmina 2,5-10x 1$4 \mathrm{~cm}$, cartácea, oval, elíptica ou oblongo-lanceolada, base arredondada, estreitamente atenuada a ocasionalmente subcordada, ápice obtuso a agudo-acuminado, margem levemente revoluta, nervuras acródromas suprabasais ou basais; face superior glabra, inferior nas folhas jovens recoberta por indumento estrelado-furfuráceo, depois glabra. Panículas 4-10cm, terminais. Flores pentâmeras; hipanto ca. $2 \mathrm{~mm}$; cálice caduco, com lacínias internas membranáceas, lobadas, externas triangulares muito reduzidas; pétalas brancas, rosadas no botão, glabras. Estames dimórficos, brancos; tecas 2,5-3mm, uniporosas; conectivo dos estames ante-sépalos dorsalmente espessado e subcalcarado, ante-pétalos basalmente trilobados. Ovário 3-4 locular, glabro; estilete levemente espessado no ápice. Baga atropurpúrea; ca. 4 sementes por lóculo.

Distribuição e habitat: Ocorre desde o Ceará até Santa Catarina. Em São Paulo é encontrada em cerrados, beira de florestas e em locais brejosos.

Material selecionado examinado: Brasil, São Paulo: Águas de Santa Bárbara, 22/II/ 1990, Meira 509(UEC); Angatuba, 19/XI/1985, Ratter 4899 \& Argent (UEC); Assis, 18/II/1988, Leitão Filho et al. 20119 (UEC); Barretos, 1917, Frazão s.n. (SP 10799); Bauru, 13/XII/1990, Azevedo 271 (UEC); Botucatu, 10/X/1985, Amaral Jr. et al. 19 (UEC). Cajuru, 17///1990, Souza \& Marcondes-Ferreira 167 (FFCLRP-USP); Campinas, s.d., Aranha, 92 (IAC); Corumbataí, 18/I/1991, Saraiva 86 (UEC); Guareí, 09/ I/1981, Neves \& Cerantola 5819 (UEC); Guarulhos, V/1941, Constantino 34 (RB); Itirapina, 22/IX/1992, Goldenberg 28488 (UEC); Joanópolis, 05/IX/1979, Leitão Filho et al. 10598(UEC); Jundiaí, 25/XII/1956, Grota 5819(UEC); Lençóis Paulista, 
12/VI/1995, Tamashiro 1112 et al. (UEC); Luiz Antônio, VI/1977, Toledo \& Gianotti 6837 (UEC); Mogi das Cruzes, 19/IV/1889, Schwacke 6539 (RB); Moji Guaçu, 18/ IV/1985, Klein s.n. (UEC 37048); Mogi Mirim, 03/V/1983, Alvares 21939 (UEC); Pedra Bela, 08/V/1995, Tamashiro 946 et al. (UEC); Pirassununga, 29/X/1978, F. R. Martins 9984 (UEC); Porto Ferreira, 22/XII/1981, Bertoni 1684 (UEC); Rio Claro, 04/IV/1991, Romero 308 (UEC); Santa Rita do Passa Quatro, I/1986, Castro 19723 (UEC); São José dos Campos, 12/XII/1986, Silva 1524 \& Capellari Jr. (UEC); São Paulo, 26/XI/1945, Hoehne s.n. (SPF 13686); s.d., Navarro de Andrade s.n. (SP 10821); Serra Negra, 11/VIII/1990, Simão-Bianchini 245 (UEC); Socorro, 09/V/ 1995, Tamashiro 994 et al (UEC).

Miconia ligustroides é uma espécie polimórfica, variando principalmente quanto à forma e tamanho das folhas e presença ou ausência de indumento nas partes adultas da planta. Apresenta semelhanças com M. minutiflora (Bonpl.) DC., da qual difere principalmente por esta última possuir folhas geralmente maiores, com maior número de nervuras, conectivo dos estames ante-pétalos com cálcar mais pronunciado e agudo, pétalas com tricomas glandulares e cálice com lacínias internas ciliadas. Vários materiais pertencentes a esta espécie, inclusive alguns citados por Hoehne (1922) - Frazão s.n. (SP 10799) e Navarro de Andrade s.n. (SP 10821) - foram identificados como $M$. candolleana Triana, sinônimo de $M$. cinnamomifolia.

\section{Miconia macrothyrsa Benth. J. Bot. (Hooker) 2: 312. 1840. Seção Miconia- Seriatiflorae. \\ Fig.le}

Arbustos até $3 \mathrm{~m}$. Ramos, pecíolos, hipanto e cálice densamente revestidos por indumento furfuráceo-granuloso com tricomas curto estrelados a penicelados ferrugíneos. Folhas com pecíolo até $1 \mathrm{~cm}$; lâmina $6-15 \times 3-10 \mathrm{~cm}$, coriácea, oval, oblonga, largamente elíptica até suborbicular, base arredondada a subcordada, ápice obtuso a arredondado, às vezes curtamente acuminado, margem inconspicuamente serreada e estrigosa, nervuras acródromas basais; face superior das folhas jovens furfurácea, depois glabra, face inferior densamente recoberta por indumento furfuráceo ferrugíneo. Panículas escorpióides, até $15 \mathrm{~cm}$. Flores pentâmeras; hipanto $3 \mathrm{~mm}$; cálice persistente, com lacínias internas arredondadas e externas triangulares tuberculadas; pétalas brancas ou creme. Estames dimórficos, creme ou amarelados; tecas 2,5-3mm, uniporosas; conectivo bastante espessado no dorso, moderadamente prolongado abaixo das tecas, nos estames ante-sépalos basalmente projetado em apêndices ventrais longos, crassos e truncados, estames ante-pétalos com projeções semelhantes, mais curtas. Ovário 3-locular, glabro; estilete filiforme. Baga vermelha, atropurpúrea quando madura; sementes numerosas, cerca de 10 por lóculo.

Distribuição e habitat: Ocorre na Venezuela, Guiana e Brasil, nos Estados de Roraima, Mato Grosso, Goiás, Minas Gerais, Rio de Janeiro e São Paulo. Espécie característica de cerrado. 
Material selecionado examinado: Brasil, São Paulo: Cajuru: 19/VIII/1989, Sciamarelli \& Nunes 142 (UEC); 18/I/1990, Sciamarelli \& Nunes 444 (FFCLRP-USP).

35. Miconia minutiflora (Bonpl.) DC., Prodr. 3: 189. 1828. Melastoma minutiflora Bonpl. in Humb. \& Bonpl., Monogr. Melast. 1: 50. 1809. Seção Glossocentrum.

Arbustos a árvores 1-6(-8)m. Ramos, pecíolos e eixos das inflorescências esparsamente recobertos por indumento estrelado-furfuráceo, logo glabrescentes, permanecendo alguns tricomas nos nós dos ramos e eixos das inflorescências. Folhas com pecíolo ca. $0,5 \mathrm{~cm}$; lâmina $6-12 \times 2,5-4 \mathrm{~cm}$, membranácea, oblongo-lanceolada, base atenuada a arredondada, ápice acuminado até caudado, margem sinuosa revoluta, nervuras acródromas basais; ambas as faces das folhas jovens estrelado-furfuráceas, depois glabras. Panículas até $11 \mathrm{~cm}$, terminais. Flores pentâmeras; hipanto $\mathrm{i}-1,5 \mathrm{~mm}$; cálice caduco, com lacínias internas lobadas e cilioladas, externas constituídas por dentículos pouco conspícuos; pétalas brancas, rosadas no botão, ápice esparsamente ciliado-glanduloso. Estames dimórficos, brancos; tecas 2 ou 2,5mm, uniporosas; conectivo dos estames ante-sépalos espessado no dorso e basalmente expandido em projeção arredondada, estames ante-pétalos com conectivo calcarado no dorso, ventralmente biapendiculado. Ovário 3-locular, glabro; estilete levemente espessado no ápice. Baga atropurpúrea; sementes pequenas e numerosas por lóculo.

Distribuição e habitat: Ocorre desde o sul do México e Caribe até o sudeste do Brasil. Em São Paulo é encontrada em vegetação secundária, borda de florestas e cerrados.

Material selecionado examinado: Brasil, São Paulo: Cajuru, 28/III/1985, Bernacci 4 (SP); Itirapina, 07/II/1993, Goldenberg 28490 (UEC); Itu, 20/IV/1898, Russel 350 (SP).

36. Miconia paniculata (Mart. et Schrank ex DC.) Naudin, Ann. Sci. Nat. Bot., ser. 3, 16: 245. 1850. Cremanium paniculatum DC., Prodr. 3: 194. 1828. Seção Glossocentrum.

Arbustos ca. $2 \mathrm{~m}$. Ramos, pecíolos, eixos das inflorescências, hipanto e cálice densa a moderadamente recobertos por indumento estrelado a furfuráceo, posteriormente glabrescentes. Folhas com pecíolo $0,5-1 \mathrm{~cm}$; lâmina 3-9x1,5-3cm, cartácea, oval, base atenuada a ligeiramente arredondada, ápice acuminado a caudado, margem repanda, às vezes revoluta, nervuras acródromas suprabasais, na face inferior unidas à base da nervura central por membrana; face superior glabra, inferior esparsamente recoberta por indumento furfuráceo ou glabra. Panículas $4-8 \mathrm{~cm}$; bractéolas lineares, persistentes. Flores pentâmeras; hipanto 2-2,5 mm; cálice caduco, com lacínias internas membranáceas, triangulares, ápice arredondado, externas triangulares, mais curtas; pétalas brancas. Estames 10, isomórficos, brancos; tecas ca. $2 \mathrm{~mm}$, uniporosas; 
conectivo pouco espessado no dorso, com cálcar basal arredondado. Ovário 2-3 locular, glabro; estilete filiforme. Baga atro-púrpurea; uma semente por lóculo.

Distribuição: Ocorre em Minas Gerais, Rio de Janeiro e São Paulo.

Material selecionado examinado: Brasil, São Paulo: Caraguatatuba, 25/05/1985, Montouché 1739 (UEC); Miracatu, 08/VIII/1984, Martuscelli 46 (SP); Paraibuna, 26/III/1984, Shepherd \& Tamashiro 15830 (UEC).

O material vegetativo de Miconia paniculata se assemelha muito ao de algumas es-pécies da sec. Chaenanthera por apresentar a base das nervuras unidas por uma membrana, mas delas difere pelas anteras poricidas. Mais comentários em $M$. doriana.

37. Miconia pepericarpa Mart. ex DC., Prodr. 3: 182. 1828. Seção Glossocentrum.

Arbustos 2-3m ou árvores até $5 \mathrm{~m}$. Ramos, pecíolos, eixos das inflorescências, hipanto e cálice recobertos por indumento denso estrelado-sublepidoto e furfuráceo, canescente a ocráceo, com raros tricomas dendríticos esparsos. Folhas com pecíolo 0,5-1,5cm; lâmina 4-12x1-3cm, cartácea, oblongo-lanceolada, base arredondada, ápice acuminado, margem inteira revoluta, nervuras acródromas inconspicuamente suprabasais, ocasionalmente basais; face superior das folhas jovens furfurácea, depois glabra, face inferior densamente recoberta por indumento estrelado-sublepidoto. Panículas de glomérulos, até $10 \mathrm{~cm}$, pêndulas, terminais e laterais; ramos secundários curtos (até $2,5 \mathrm{~cm}$ ) com apenas um glomérulo na extremidade. Flores tetrâmeras; hipanto ca. 1,5 mm; cálice persistente, com lacínias internas curtas largamente triangulares a arredondadas, externas triangulares agudas muito reduzidas; pétalas creme, cuculadas. Estames isomórficos, creme; tecas ca. $1,5 \mathrm{~mm}$, uniporosas; conectivo espessado no dorso, curtamente prolongado abaixo das tecas, inapendiculado. Ovário 2-3 locular, estrigoso no ápice; estilete levemente espessado no ápice. Baga azulpálido (negra no material seco); uma semente por lóculo.

Distribuição e habitat: Ocorre em Goiás, Distrito Federal, Bahia, Minas Gerais e São Paulo. Neste Estado é encontrada em cerrados fechados e bordas de mata.

Material selecionado examinado: Brasil, São Paulo: Cajuru, 22/X/1989, Souza \& Marcondes-Ferreira 139(FFCLRP-USP); Itirapina, 21/XI/1992, Goldenberg 28485 (UEC).

Indivíduos floridos de $M$. pepericarpa podem ser identificados no campo pelo odor acre de suas flores.

38. Miconia petropolitana Cogn. in Mart., Fl. bras. 14(4): 613. 1888. Seção Glossocentrum. 
Arbustos ou arvoretas 2-4m. Ramos jovens, eixos das inflorescências e hipanto esparsa a moderadamente recobertos por indumento estrelado-furfuráceo, glabrescentes, à exceção do hipanto. Folhas com pecíolo 0,5-1,5cm; lâmina 5-10,5x1,5-4cm, membranácea, glabra, elíptica a oboval-elíptica, base longamente atenuada, ápice agudo a acuminado, margem inteira ou subdenticulada, nervuras acródromas basais; ambas as faces glabras. Panículas tirsóideas, 3-6cm, terminais. Flores pentâmeras; hipanto ca. $2 \mathrm{~mm}$; cálice persistente, com lacínias internas triangulares, ciliadas, externas inconspícuas, tuberculadas; pétalas brancas. Estames subisomórficos, brancos; tecas ca. 1,5mm, alargadas no ápice, uniporosas; conectivo espessado, giboso, ventralmente prolongado abaixo das tecas, nos estames ante-sépalos calcarado no dorso, nos ante-pétalos com projeção alargada, bilobada no dorso. Ovário 3-locular, levemente estrelado-furfuráceo no ápice; estilete levemente espessado no ápice. Baga com poucas sementes por lóculo.

Distribuição e habitat: Ocorre em Minas Gerais, Rio de Janeiro, São Paulo, Paraná e Santa Catarina. Em São Paulo é encontrada em subosque de diversas formações florestais.

Material selecionado examinado: Brasil, São Paulo: Campinas, 18/X/1990, Moraes et al. 23611 (UEC); Jundiaí, IX/1995, Goldenberg 94 (UEC); Limeira, s.d., Kuhn 16 (SP); Manduri, 13/VI/1995, Tamashiro 963 et al. (UEC); Pedra Bela, 08/V/1995, Tamashiro 1166 et al. (UEC); São Paulo, 22/VIII/1931, Hoehne s.n. (SP 28271); Ubatuba, 21/VIII/1976, Davis 59796 et al. (UEC); Vinhedo, 25/VIII/1983, Rocha 15565 (UEC).

39. Miconia pohliana Cogn. in Mart., Fl. bras. 14(4): 349-350. 1887. Seção MiconiaPaniculares.

Fig.11

Arbustos ou árvores até $5 \mathrm{~m}$. Ramos jovens, pecíolos, eixos das inflorescências, hipanto e cálice densamente recobertos por indumento estrelado-furfuráceo a dendrítico-tomentoso, ocráceo. Folhas com pecíolo 0,5-1 cm; lâmina 4-10×2,5-6cm, coriácea, oval a oval-elíptica, base arredondada a cordada, ápice obtuso, agudo ou ocasionalmente arredondado, mucronado, margem inteira ou denteado-ciliada, nervuras acródromas basais; face superior das folhas jovens estrelado-furfurácea, depois glabra, face inferior moderada a densamente recoberta - mas sempre deixando visível a superfície da folha - por indumento estrelado-furfuráceo a dendrítico-tomentoso ocráceo. Panículas de glomérulos, até $10 \mathrm{~cm}$. Flores pentâmeras; hipanto ca. $2 \mathrm{~mm}$; cálice persistente, com lacínias internas curtas, triangulares, externas tuberculadas, inconspícuas; pétalas brancas. Estames subisomórficos, brancos; tecas ca. 1,5mm, uniporosas; conectivo longamente prolongado abaixo das tecas, giboso e curtamente calcarado no dorso, com aurículas ventrais curtas. Ovário 3-locular, glabro; estilete levemente espessado no ápice. Baga arroxeada; sementes 5-8 por lóculo. 
Distribuição e habitat: Ocorre em Goiás, Distrito Federal, Minas Gerais e São Paulo, em cerrados.

Material selecionado examinado: Brasil, São Paulo: Brotas, VI/1961, Eiten et al. 2960 (SP); Franca, IV/1920, Gehrt s.n. (SP 4033); Itirapina, 29/IV/1923, Gehrt s.n. (SP 832).

O material citado por Hoehne (1922) como Miconia leucocarpa DC. - Gehrt s.n. (SP 4033) - pertence a M. pohliana.

40. Miconia prasina (Sw.) DC., Prodr. 3: 188. 1828. Melastoma prasina Sw., Prodr.: 69. 1788. Seção Miconia-Paniculares. Fig. $1 \mathrm{~m}$

Arvoretas ou árvores até 10m. Ramos, pecíolos, brácteas, bractéolas, eixos das inflorescências e hipanto esparsamente revestidos por indumento estrelado-pubérulo, glabrescente. Folhas com pecíolo $0,3-2,5 \mathrm{~cm}$, alado por toda sua extensão ou apenas parte; lâmina 9-20x3,5-7cm, cartácea a subcoriácea, elíptica a oblonga ou ovalelíptica, base atenuada e decurrente, ápice agudo a acuminado, margem inteira a repanda-denticulada, nervuras acródromas suprabasais; face superior glabra, inferior com indumento estrelado-pubérulo esparso recobrindo apenas as nervuras. Panículas até $25 \mathrm{~cm}$, terminais. Flores pentâmeras; hipanto ca. $4 \mathrm{~mm}$; cálice persistente, com lacínias internas e externas fundidas, triangulares; pétalas brancas. Estames subisomórficos, brancos; tecas ca. $3 \mathrm{~mm}$, uniporosas; conectivo muito espessado no dorso, ventralmente biauriculado. Ovário 3-locular, ápice lobado curtamente glanduloso; estilete levemente espessado no ápice. Baga roxa; sementes numerosas por lóculo.

Distribuição e habitat: Ocorre na Amércia Central, Caribe, Venezuela, Guianas e Brasil, nos Estados do Amazonas, Pará, Pernambuco, Bahia, Minas Gerais, Espírito Santo, Rio de Janeiro e São Paulo. Neste Estado é encontrada principalmente em formações florestais costeiras.

Material selecionado examinado: Brasil, São Paulo: Caraguatatuba, 22/VIII/1976, Davis et al. 59896 (UEC); Guarujá, 05/XI/1986, Leitão Filho et al. 18756 (UEC); Santos, 11/VI/1992, Kawall 209 (SP); Ubatuba, 19/III/1978, Silva 8000 (UEC).

Miconia prasina se distingue de Miconia chamissois e de $M$. elegans pelos estames com conectivo ventralmente biauriculado e pelo habitat. As duas outras espécies possuem conectivo dorsalmente prolongado e ocorrem em formações vegetais de planalto, em áreas brejosas.

41. Micona pseudonervosa Cogn. in Mart., Fl. bras. 14(4): 337. 1887. Seção Miconia-Paniculares.

Fig.1n 
Arbustos até $3 \mathrm{~m}$. Ramos, pecíolos, eixos das inflorescências, hipanto e cálice densamente recobertos por tricomas seríceo-lanosos, ocasionalmente glandulares. Folhas com pecíolo $1,4-4 \mathrm{~cm}$; lâmina $7-25 \times 3-10 \mathrm{~cm}$, membranácea a cartácea, elíptica a elíptico-lanceolada, base cuneada a atenuada e curtamente decurrente, ápice agudo a acuminado, margem curtamente serreado-denteada e ciliada, nervuras acródromas suprabasais, o último par disposto $1,5 \mathrm{a} 4 \mathrm{~cm}$ acima da base; face superior esparsamente hirsuta e densamente estrigosa sobre as nervuras, face inferior densamente lanosovilosa, mas deixando a superfície da folha visível. Panículas de glomérulos, $6,5-15 \mathrm{~cm}$, eixos frequentemente avermelhados. Flores pentâmeras; hipanto 2-3mm; cálice persistente, com lacínias internas truncadas e externas triangulares, agudas; pétalas brancas ou róseas. Estames subisomórficos, brancos; tecas 2,5-4mm, levemente corrugadas, uniporosas. Ovário 3-locular, setuloso no ápice; estilete filiforme. Baga alaranjada quando jovem, azul-pálido quando madura; sementes pequenas e numerosas, ca. 40 por lóculo.

Distribuição e habitat: Ocorre em Goiás, Distrito Federal, Minas Gerais, Rio de Janeiro e São Paulo. Neste Estado é encontrada em locais alagados, em áreas de domínio de vegetação de cerrado e de floresta.

Material selecionado examinado: Brasil, São Paulo: Brotas, 15/IV/1992, Goldenberg, 44 (UEC); Campinas, 31/VIII/1983, Baldassari \& Monteiro Filho 15115 (UEC); Itirapina, 27/VI/1985, Cesar 551 (SP); Teodoro Sampaio, 22/I/1986, Martuscelli 206 (SP); Valinhos, s.d., Campos Novaes s.n. (SP 7469).

Exemplares desta espécie são semelhantes a indivíduos do gênero Leandra. não só no aspecto geral, mas também pelos botões agudos e pétalas mais estreitas e alongadas. Miconia pseudonervosa é muito próxima de M. nervosa (Sm.) Triana, da qual difere pelas folhas distintamente pecioladas, com lâmina decurrente. É possível que constituam um único taxon polimórfico e politípico. O material tipo de $M$. camposnovaesii Hoehne - Campos Novaes s.n. (SP 7469) - não difere dos materiais de M. pseudonervosa.

42. Miconia racemifera (Schrank et Mart. ex DC.) Triana, Trans. Linn. Soc. Bot. 28: 119. 1871. Melastoma racemifera Schrank et Mart. ex DC., Prodr. 3: 155. 1828. Seção Glossocentrum.

Árvores 3,5-8m. Ramos, pecíolos, eixos das inflorescências e hipanto densamente recobertos por indumento estrelado ferrugíneo-ocráceo. Folhas com pecíolo 0,5-1,5cm; lâmina 10-27×3-8,5cm, cartácea, lanceolada a oblonga ou elíptico-oblonga, base atenuada a levemente arredondada, ápice agudo e acuminado, margem denteada a serreada ou subíntegra, nervuras acródromas suprabasais ou obscuramente basais; face superior das folhas jovens estrelado-furfurácea, depois glabra, face inferior moderadamente recoberta por indumento estrelado ferrugíneo a ocráceo. 
Panículas de glomérulos, $12-19 \mathrm{~cm}$. Flores tetrâmeras; hipanto ca. $2,5 \mathrm{~mm}$; cálice caduco, com lacínias internas triangulares, curtas, externas mais longas, triangularsubuladas; pétalas brancas, cuculadas. Estames isomórficos; tecas ca. $2 \mathrm{~mm}$, uniporosas; conectivo curtamente prolongado na base, inapendiculado. Ovário 3-4 locular, setuloso no ápice; estilete filiforme. Frutos e sementes não vistos.

Distribuição e habitat: Ocorre em Minas Gerais, Rio de Janeiro e São Paulo. Neste Estado ocorre em florestas, em locais úmidos.

Material selecionado examinado: Brasil, São Paulo: São Paulo, 12/XII/1901, Hammars.n. (SP 4789); 30/X/1906, Usteri s.n. (SP 11897); 06/XII/1943, Rotti 777 (SP); Parque Estadual de Carlos Botelho, 16/XII/1987, Dias /14 (SP).

43. Miconia rigidiuscula Cogn. in Mart., Fl. bras. 14(4): 398. 1888. Seção Chaenanthera.

Árvoretas $2 \mathrm{~m}$ a árvores até $15 \mathrm{~m}$. Ramos, pecíolos, eixos das inflorescências, hipanto e cálice densamente recobertos por indumento estrelado-furfuráceo, posteriormente subglabrescentes a glabrescentes. Folhas com pecíolo $0,5-1,5 \mathrm{~cm}$; lâmina 4$18 \times 1,5-4,5 \mathrm{~cm}$, cartácea, elíptica, oboval a elíptico-oblonga, base atenuada a decurrente, ápice longamente cuspidado-caudado, margem denticulada-serreada nos $2 / 3$ superiores, nervuras acródromas basais, raramente suprabasais; face superior glabra, inferior apenas com as nervuras esparsamente estrelado-furfuráceas. Panículas 4$12 \mathrm{~cm}$. Flores pentâmeras; hipanto ca. $1,5 \mathrm{~mm}$; cálice caduco, com lacínias internas triangulares, membranáceas, glabras, externas triangulares, do mesmo tamanho ou pouco menores; pétalas brancas. Estames isomórficos, brancos; tecas ca. 1,5mm, rimosas até a base; conectivo levemente prolongado abaixo das tecas, não apendiculado. Ovário 3-locular, glabro ou furfuráceo no ápice; estilete levemente espessado no ápice. Baga atropurpúrea; semente 1 por lóculo.

Distribuição e habitat: Ocorre desde o Rio de Janeiro até o Rio Grande do Sul. Em São Paulo é encontrada em formações florestais próximas à costa e, no Vale do Ribeira, em florestas em altitudes próximas ao nível do mar.

Material selecionado examinado: Brasil, São Paulo: Cananéia, 11-16/IV/1987, Chiea 542 (SP); 02/II/1978, Prance et al. 6939 (UEC); 05/IV/1978, De Grande \& Lopes 65 (SP); 08/VI/1979, De Grande \& Lopes 305 (SP); 20/V/1988, Leitão Filho et al. 20351 (UEC); Capão Bonito, 09/X/1989, Alvares 23329 (UEC); Pariquera-Açu, 07/ II/995, Leitão Filho et al. 33065 (UEC); Praia Grande, 21/III/1932, Hoehne s.n. (SP 29356); São Miguel Arcanjo, 04/IV/1990, Moraes S.I (ESA); Ubatuba, 17/III/1991, Romero et al. 247 (HRCB).

Miconia rigidiuscula se distingue de $M$. hymenonervia pelas folhas com base 
atenuada a decurrente e pelo habitat, sendo que $M$. rigidiuscula ocorre em florestas a baixas altitudes, enquanto $M$. hymenonervia tem sido principalmente coletada no planalto ou nas encostas altas da mata atlântica. Exemplares coletados na Ilha do Cardoso, Cananéia, apresentam folhas com base mais arredondada e nervuras unidas por membrana, características estas encontradas em M. hymenonervia. Entretanto, outros aspectos das plantas, como as lacínias do cálice e o habitat, nos permitem considerar os exemplares De Grande \& Lopes 305, De Grande \& Lopes 65, Leitão Filho et al. 20351 e Prance et al. 6939, como pertencentes a M. rigidiuscula.

44. Miconia rubiginosa (Bonpl.) DC., Prodr. 3: 183. 1828. Melastoma rubiginosa Bonpl., Monogr. Melast. 1: 109. 1816. Seção Miconia-Paniculares. Fig.lo

Arbustos ca. $1 \mathrm{~m}$ ou arvoretas até $5 \mathrm{~m}$. Ramos, pecíolos, eixos das inflorescências, hi-panto e cálice densa a esparsamente recobertos por indumento pubérulo-estrelado e tricomas penicelados, ferrugíneos, esparsos. Folhas com pecíolo $0,4-1 \mathrm{~cm}$; lâmina 7 $14 \times 2,5-5 \mathrm{~cm}$, coriácea, oval-oblonga a oblongo-elíptica, base arredondada, ápice agudo a curtamente acuminado, margem inteira, nervuras acródromas basais; face superior das folhas jovens com tricomas estrelados a furfuráceos ferrugíneos, posteriormente glabra, face inferior moderada a densamente recoberta - mas sempre deixando visível a superfície da folha - por indumento estrelado-estipitado ferrugíneo. Panículas $12-18 \mathrm{~cm}$. Flores pentâmeras; hipanto ca. $2 \mathrm{~mm}$; cálice caduco, com lacínias internas triangulares, obtusas, externas inconspícuas; pétalas brancas. Estames dimórficos, brancos; tecas 2$2,5 \mathrm{~mm}$, uniporosas; conectivo dos estames ante-pétalos curtamente prolongado, espessado e calcarado no dorso, ante-sépalos com apêndice basal cordiforme ou trilobado, ambos com aurículas ventrais diminutas. Ovário 3-locular, glabro; estilete levemente espessado no ápice. Baga violácea; poucas sementes por lóculo.

Distribuição e habitat: Ocorre desde a Costa Rica até a Bolívia e Brasil. É comum nos cerrados brasileiros, sendo encontrada em Mato Grosso, Goiás, Bahia, Minas Gerais e São Paulo.

Material selecionado examinado: Brasil, São Paulo: Botucatu, III/1986, Hernandes Bicudo et al. 688 (UEC); Casa Branca, XI/1979, Toledo Filho 10729 (UEC); Itirapina, VII/1984, Arasaki 8 (UEC); Moji Guaçu, X/1982, Martins 14305 (UEC); Luiz Antônio, XII/1978, Toledo Filho 9902 (UEC); Porto-Ferreira, XII/1981, Bertoni 16883 (UEC); Santa Rita do Passa Quatro, I/1986, Castro 19722 (UEC); São Carlos, IX/1980, Semir et al. 11539 (UEC).

45. Miconia saldanhaei Cogn. in Mart., Fl. bras. 14(4): 372. 1887. Seção Glossocentrum.

Arbustos 1,5-2m a árvores até $6 \mathrm{~m}$. Ramos, pecíolos, eixos das inflorescências e hipanto densamente recobertos por indumento dendrítico a estrelado ocráceo a 
ferrugíneo, nas partes jovens entremeado por tricomas longos ramificados na base; face inferior das folhas com tricomas esparsos. Folhas com pecíolo $1-1,5 \mathrm{~cm}$; lâmina 13-32x14-16 cm, cartácea, oblonga a elíptica, base atenuada, ápice agudo a acuminado, margem esparsa e curtamente denticulada; nervuras acródromas basais a irregularmente suprabasais; face superior das folhas jovens com tricomas estrelados, depois glabra, face inferior moderadamente recoberta por indumento dendrítico a estrelado, ocráceo a ferrugíneo. Panículas piramidais de glomérulos, $11-22 \mathrm{~cm}$; ramos secundários basais longos $(3,5-12 \mathrm{~cm})$ com até 8 glomérulos. Flores pentâmeras ou tetrâmeras; hipanto ca. $2 \mathrm{~mm}$; cálice persistente, com lacínias internas triangulares, externas triangular-tuberculadas, mais curtas; pétalas brancas, cuculadas. Estames isomórficos, brancos; tecas ca. 1,5mm, linear-obovadas, uniporosas; conectivo longamente prolongado na base, inapendiculado. Ovário 3-locular, piloso no ápice; estilete filiforme. Frutos e sementes não vistos.

Distribuição e habitat: Ocorre no Rio de Janeiro e São Paulo. Neste Estado é encontrada em formações florestais litorâneas e sobre a Serra do Mar.

Material selecionado examinado: Brasil, São Paulo: Cananéia, 08/IX/1972, Davis et al. D.60722 (UEC); Bertioga, 29/XI/1989, Grombone et al. 22860 (UEC); São Bernardo do Campo, 19/XII/1990, Esteves 23 (SP); São Paulo, 1917, Frazão s.n. (SP 10769); Ubatuba, 10/XI/1990, Furlan et al. 1284 (UEC).

A espécie é próxima de $M$. racemifera, que apresenta cálice com lacínias externas mais longas e agudas, folhas com margem menos denticulada e inflorescências com glomérulos mais laxos. As flores de $M$. saldanhaei exalam um odor doce, levemente desagradável. O material citado por Hoene (1922) como M. fasciculata Gardner-Frazão s.n. (SP 10769) - pertence à M. saldanhaei.

46. Miconia sellowiana Naudin, Ann. Sci. Nat. Bot., ser. 3, 16: 206. 1851. Seção Chaenanthera.

Fig.2f

Arbustos $2 \mathrm{~m}$ até árvores $11 \mathrm{~m}$. Ramos, pecíolos, eixos das inflorescências, hipanto e cálice recobertos por indumento estrelado-furfuráceo, posteriormente glabros. Folhas com pecíolo $0,5-1 \mathrm{~cm}$; lâmina $5-11 \times 1-3 \mathrm{~cm}$, cartácea a membranácea, lanceolada a oblongo-lanceolada, base atenuada e decurrente, ápice acuminado a caudado, margem distintamente serreada exceto no terço inferior, nervuras acródromas suprabasais, em geral unidas à base da nervura central por membrana, par marginal basal ocasionalmente presente; ambas as faces das folhas jovens esparsamente estrelado-furfuráceas, depois glabras. Panícula tirsóidea, 4-8cm. Flores pentâmeras; hipanto ca. $2 \mathrm{~mm}$; cálice caduco, com lacínias internas membranáceas, arredondadas, cilioladas, externas triangulares, estreitas; pétalas brancas. Estames isomórfi$\cos$, brancos; tecas ca. $2 \mathrm{~mm}$, com poro muito amplo e inclinado (à semelhança de uma rima), atingindo ca. 1/3 do compr. da teca; conectivo ligeiramente prolongado abaixo 
das tecas e obscuramente bilobado ventralmente. Ovário 3-locular, papiloso no ápice; estilete levemente espessado no ápice. Baga atropurpúrea; sementes 2-3 por lóculo.

Distribuição e habitat: Ocorre desde Goiás e Minas Gerais até o Rio Grande do Sul. Em São Paulo é encontrada em cerrados e algumas formações florestais.

Material selecionado examinado: Brasil, São Paulo: Águas de Santa Bárbara, 09/X/ 1990, Meira Neto 710 et al. (UEC); Atibaia, 26/X/1983, Marcondes-Ferreira 15067 (UEC); Campos do Jordão, 29/IX/1966, Davis et al. 3038(UEC); entre Campos do Jordão e Piranguçu, 21/X/1989, Pirani 2518 ct al. (SP, UEC); Corumbataí, 26/VI/ 1985, Federsen Jr. I (HRCB, UEC); Joanópolis, 14/X/1994, Arbocz 921 (UEC); Jundiaí, 22/IX/1983, Sugiyama \& Chiea 15527 (UEC); São Paulo, VIII/1940, Hoehne s.n. (UEC 61610).

Conforme já salientado por Wurdack (1962), embora esta espécie tenha sido atribuída por Cogniaux (1887/1888) à seção Chaenanthera, a estrutura das anteras é mais parecida com a de espécies da seção Glossocentrum.

47. Miconia serrulata (DC.) Naudin, Ann. Sci. Nat. Bot., ser. 3, 16: 118. 1850. Diplochita serrulata DC., Prodr. 3: 177. 1828. Seção Tamonea.

Arbustos ca. $2 \mathrm{~m}$. Ramos, pecíolos, eixos das inflorescências, hipanto e cálice den samente recobertos por tricomas furfuráceos, mesclados com tricomas estreladodendríticos curtos. Folhas com pecíolo $1,8-4 \mathrm{~cm}$; lâmina $15-28 \times 6-10 \mathrm{~cm}$, cartácea, elíptica a oblonga, base cordada, ápice agudo a curtamente acuminado, margem serrulada, nervuras acródromas basais; face superior das folhas jovens com tricomas estrelados, depois glabras, face inferior densamente recoberta por tricomas estrelados. Panículas $20-26 \mathrm{~cm}$. Flores hexâmeras e pentâmeras, brácteas caducas, $4-11 \mathrm{~mm}$ compr.; hipanto 5-8,5mm, 10-12 sulcado; cálice persistente, com lacínias internas agudas a obtusas, externas não evidentes; pétalas brancas. Estames subisomórficos, purpúreos; tecas 5,5-8mm, uniporosas; conectivo não prolongado abaixo das tecas, inconspicuamente tuberculado e muitas vezes glandular-pubérulo em sua porção dorso-basal; filetes esparso a moderadamente pubérulos. Ovário 3-5 locular, piloso no ápice; estilete densamente estrelado na metade inferior, levemente espessado no ápice. Baga cinérea, sulcada; sementes pequenas e numerosas por lóculo.

Distribuição e habitat: Ocorre desde o sul do México e Caribe até a Bolívia e sudeste do Brasil. Em São Paulo ocorre em restinga arbórea.

Material examinado: Brasil, São Paulo: Ubatuba, 19/VII/1939, Smith s.n. (IAC 4838); 24/VI/1986, Kirizawa 1673 (SP).

Os exemplares coletados em São Paulo apresentam apenas frutos; por isso as 
características florais mencionadas estão de acordo com Wurdack (1973) e Baumgratz (1982).

48. Miconia stenostachya Schrank \& Mart. ex DC., Prodr. 3: 181. 1828. Seção Miconia-Seriatiflorae.

Arbustos até $2 \mathrm{~m}$. Ramos, pecíolos, brácteas, bractéolas, hipanto e cálice densamente revestidos por indumento estrelado canescente. Folhas com pecíolo $0,5-2,5 \mathrm{~cm}$; lâmina $7-16 \times 3,5-7 \mathrm{~cm}$, cartácea, oval-lanceolada a lanceolada, base obtusa, ápice arredondado a levemente acuminado, margem levemente crenada, nervuras acródromas basais; face superior glabra, inferior densamente revestida por indumento estrelado canescente. Panículas escorpióides, ca. $15 \mathrm{~cm}$. Flores pentâmeras; hipanto $3 \mathrm{~mm}$; cálice persistente, com lacínias internas e externas fundidas, triangulares, com ápice agudo; pétalas brancas, margem ciliado-glandulosa. Estames isomórficos, amarelos; tecas ca. $4 \mathrm{~mm}$, uniporosas, conectivo espessado no dorso e levemente calcarado na base. Ovário 3-locular, glabro; estilete levemente espessado no ápice. Baga madura atropurpúrea; sementes numerosas, ca. 15 por lóculo.

Distribuição e habitat: Ocorre desde o sul do México até a Bolívia. No Brasil ocorre desde os Estados do Pará e Amazonas até o Paraná, em cerrados.

Material selecionado examinado: Brasil, São Paulo: Águas de Santa Bárbara, 30/ VIII/1990, Meira Neto 612 (UEC); Anhembi, 16/X/1981, César s.n. (UEC 53890); Assis, 12/VIII/1992, Durigan 308 (UEC); Cajuru, 24/IX/1989, Sciamarelli \& Nunes 282 (UEC); Guareí, 30/VII/1980, Neves \& Cerantola 15 (UEC); Itirapina, 23/VII/ 1982, César \& Pagano 9 (UEC); Itu, 22/X/1987, Silva \& Souza 25524 (UEC); Moji Guaçu, 15/IX/1980, Mantovani 941 (UEC); Mogi Mirim, X/1978, Toledo Filho 9889 (UEC); Pirassununga, 13/IV/1977, Kirizawa 107(UEC); Porto Ferreira, 14/VII/1981, Bertoni 16882 (UEC); Rio Claro, 23/X/1987, Christofoletti s.n. (UEC 61324); Santa Rita do Passa Quatro, 16/X/1975, Martins \& Vasconcellos 12388 (UEC); Santo Antonio de Posse, 19/VIII/1980, Gabrielli \& Tamashiro 11411 (UEC); São Paulo, 12/ IX/1945, Hoenhe s.n. (UEC 64764); Sumaré, 12/VI/1978, Yamamoto 7992 (UEC).

Comentários: ver Miconia albicans e $M$. fallax.

49. Miconia tentaculifera Naudin, Ann. Sci. Nat. Bot., ser. 3, 16: 241. 1851. Seção Chaenanthera.

Árvores 8-12m. Ramos, pecíolos, eixos das inflorescências, hipanto e cálice densamente recobertos por indumento estrelado-furfuráceo, posteriormente glabrescentes. Folhas com pecíolo $0,5-1 \mathrm{~cm}$; lâmina $6-9 \times 1-2 \mathrm{~cm}$, cartácea, oblongo-lanceolada, base aguda atenuada, ápice longamente caudado, margem remotamente serreada e ocasionalmente ciliada, nervuras acródromas basais; face superior das folhas jovens 
estrelado-furfurácea, depois glabra, face inferior moderadamente recoberta por indumento estrelado-furfuráceo canescente. Panículas $5-10 \mathrm{~cm}$. Flores pentâmeras; hipanto 1-1,5 mm; cálice caduco, com lacínias internas triangulares, membranáceas, externas mais longas, triangular-subuladas; pétalas brancas. Estames subisomórficos, brancos; tecas $1-1,5 \mathrm{~mm}$, rimosas até a base; conectivo basalmente prolongado, inapendiculado. Ovário 3-locular, furfuráceo no ápice; estilete levemente espessado no ápice. Baga e sementes não vistas.

Distribuição e habitat: Ocorre em Minas Gerais e São Paulo, em formações florestais.

Material examinado: Brasil, São Paulo: São José dos Campos, 06/III/1986, Silva 1389 \& Capellari Jr. (UEC); 09/IV/1986, Silva 1433 \& Capellari Jr. (UEC).

50. Miconia theaezans (Bonpl.) Cogn. in Mart., Fl. bras. 14(4): 419. 1888. Melastoma theaezans Bonpl., in Humb. \& Bonpl., Monogr. Melast. 1: 17. t. 9. 1807. Seção Cremanium.

Fig. $2 \mathrm{~g}$

Arbustos $1-2 \mathrm{~m}$ a raramente arvoretas $7 \mathrm{~m}$, glabros ou ocasionalmente ramos e folhas jovens com indumento furfuráceo esparso e caduco. Folhas com pecíolo 0,5$2 \mathrm{~cm}$; lâmina 2,5-10x1-4,5cm, membranácea a subcoriácea, obovada a elíptica, raramente oval, base atenuada ou arredondada, ápice curtamente acuminado, margem serrado-ciliada, nervuras acródromas basais; face superior às vezes verrucosa. Panícula tirsóidea, $5-13 \mathrm{~cm}$; bractéolas oblongas, cilioladas, caducas. Flores pentâmeras; hipanto 1,5-2mm; cálice persistente, com lacínias internas arredondadas erosas, externas triangulares mais curtas; pétalas brancas. Estames subisomórficos, brancos; tecas ca. $0,5 \mathrm{~mm}$, com 4 poros; conectivo prolongado, dorso-basalmente espessado, ventralmente bituberculado. Ovário 3-locular, glabro; estilete levemente espessado no ápice. Baga atropurpúrea; sementes pequenas e numerosas.

Distribuição e habitat: Ocorre desde a América Central até Santa Catarina. Em São Paulo é encontrada geralmente em áreas brejosas e florestas ciliares.

Material selecionado examinado: Brasil, São Paulo: Araraquara, 29/XI/1951, Hoehne s.n. (UEC 61611); Atibaia, 26/X/1983, Marcondes-Ferreira 15073 (UEC); Biritiba-Mirim, 04/01/1984, Custódio Filho 2204 (UEC); Campinas, 23/XI/1976, Gibbs et al. 4026 (UEC); Itirapina, 17/V/1985, Cesar 459 (UEC); Itapetininga, 26/X/ 1976, Gibbs et al. 3281 (UEC); Joanópolis, 16/VIII/1994, Tamashiro 498 et al. (UEC); Santa Bárbara, 26/IV/1990, Meira Neto 581 (UEC); Moji Guaçu, 09/V/1985, Esteves 75 (UEC); São Paulo, 06/I/1907, Usteri s.n. (SP 72010); idem, 04/VII/1946, Kuhlmann 3314 (UEC); Sete Barras, 24/XII/1979, Benson 10883 (UEC); Ubatuba, s.d., Viegas et al. s.n. (IAC 5469).

51. Miconia tristis Spring, Flora 20, Beibl. 2: 76. 1837. Seção Glossocentrum. 
Arbustos $2 \mathrm{~m}$ a árvores até $10 \mathrm{~m}$. Planta totalmente glabra, exceto os ramos jovens, esparsamente furfuráceos, e face superior das folhas ocasionalmente com tricomas híspidos esparsos. Folhas com pecíolos 0,5-1 cm; lâmina 5-11x1,5-3,5cm, membranácea, elíptica, base atenuada a levemente decurrente, ápice acuminado; margem inteira ondulada a esparsamente serreada e setuloso-ciliada, nervuras acródromas basais ou suprabasais. Panículas terminais e laterais, até $4 \mathrm{~cm}$. Flores pentâmeras; hipanto 11,5mm; cálice caduco, com lacínias internas arredondadas a deltóides, obscuramente cilioladas, externas tuberculadas, inconspícuas; pétalas brancas. Estames isomórficos, brancos; tecas ca. $2 \mathrm{~mm}$, uniporosas; conectivo curtamente prolongado na base, espessado e curtamente calcarado no dorso, com aurículas ventrais pouco evidentes. Ovário 3-locular, glabro; estilete levemente espessado no ápice. Baga com 5-6 sementes.

Chave para as subespécies de M. tristis

1. Face superior das folhas totalmente glabra; margem inteira, ondulada, não ciliada

1. Face superior das folhas com tricomas híspidos esparsos; margem levemente serreada e setuloso-ciliada M. tristis ssp.australis.

\section{1.a. Miconia tristis Spring ssp. tristis}

Distribuição e habitat: Ocorre na Bahia, Minas Gerais, Rio de Janeiro e São Paulo. Neste Estado é encontrada em diversas formações florestais.

Material selecionado examinado: Brasil, São Paulo: Anhembi, 1/V/1959, Kuhlmann 4514 (SP); "Caminho do Mar", 07/VIII/1990, Chiea 598(SP); Manduri, 13/VI/1995, Tamashiro 1165 et al. (UEC); Miracatú, 19/IV/1994, Pirani \& Garcia 3085 (UEC); "Pilões", 15/VII/1991, Chiea 621 (SP); São José dos Campos, 9/III/1986, Silva 139 \& Capellari Jr. (UEC).

\section{1.b. Miconia tristis ssp. australis Wurdack, Sellowia 14: 60. 1962.}

Distribuição e habitat: Ocorre em São Paulo, Paraná e Santa Catarina. Em São Paulo é encontrada em formações florestais no sul do Estado.

Material selecionado examinado: Brasil, São Paulo: Eldorado, 09/II/1995, Leitão Filho et al. 33127 (UEC); São Miguel Arcanjo, 1/II/1978, Prance et al. 6927 (UEC).

Material adicional examinado: Brasil, Paraná: Morretes, 12/1/1979, Hatschbach 41867 (UEC).

Exemplares de Miconia tristis são vegetativamente semelhantes a indivíduos de 
Miconia sec. Chaenanthera, distinguindo-se destes pelas anteras poricidas. M. tristis pode ser reconhecida por apresentar panículas curtas terminais e laterais, pelas folhas enegrecidas na face superior quando secas, permanecendo manchas claras ao longo das nervuras. Miconia tristis ssp. australis, descrita por Wurdack (1962) como en-dêmica em Santa Catarina, foi encontrada em São Paulo e no Paraná.

52. Miconia urophylla DC., Prodr. 3: 186. 1828. Seção Chaenanthera.

Fig.2d

Arbustos até 2,5m. Ramos, pecíolos e hipanto densamente recobertos por indumento curto estrelado, estipitado ou não. Folhas com pecíolo $0,5-1 \mathrm{~cm}$; lâmina $3,5-10 \times 1-2,5 \mathrm{~cm}$, cartácea, lanceolada a oval-lanceolada, base aguda a arredondada, ápice caudado a acuminado, margem inteira, nervuras acródromas basais e suprabasais; face superior bulada e glabra, inferior moderadamente recoberta por tricomas estrelados a estipitados ou glabrescente. Panícula $5-9 \mathrm{~cm}$. Flores pentâmeras; hipanto ca. 1,5mm; cálice com lacínias internas arredondadas, externas triangular-tuberculadas, ambas ciliadas; pétalas brancas. Estames subisomórficos; tecas ca. 1,5mm, rimosas até a base; conectivo pouco espessado no dorso, inapendiculado. Ovário 3locular, glabro; estilete levemente espessado no ápice. Baga e sementes não vistas.

Distribuição e habitat: Ocorre em Minas Gerais, Rio de Janeiro e São Paulo. Neste Estado foi encontrada apenas uma vez, em vegetação secundária.

Material examinado: Brasil, São Paulo: São José dos Campos, 12/XI/1962, Mimura 564 (SP).

53. Miconia valtherii Naudin, Ann. Sci. Nat. Bot., ser. 3, 16: 361. 1850. Seção Glossocentrum.

Arbustos a árvores 4-6m. Ramos jovens, pecíolos, eixos das inflorescências, hipanto e cálice densamente recobertos por indumento estrelado-dendrítico. Folhas com pecíolo 0,7-3cm; lâmina 6,5-24×2-8,5cm, membranácea a sub-coriácea, elíptica a oval lanceolada, base atenuada a arredondada, ápice agudo a acuminado, margem inteira no terço inferior, ondulado-serreada na parte superior, nervuras acródromas basais; face superior das folhas jovens com tricomas estrelado-dendríticos, depois glabra, face inferior moderadamente recoberta por tricomas estrelado-dendríticos, raramente glabrescente. Panículas escorpióides, 9-17cm; bractéolas ca. $3 \mathrm{~mm}$, persistentes. Flores pentâmeras; hipanto ca. 1,5mm; cálice persistente, com lacínias internas triangulares, externas tuberculadas; pétalas brancas. Estames isomórficos, brancos; tecas 1-1,2 mm, uniporosas; conectivo prolongado $0,8-1 \mathrm{~mm}$ abaixo das tecas, levemente calcarado no dorso e inconspicuamente apendiculado na face ventral. Ovário trilocular, glabro, estilete abruptamente alargado no ápice. Baga com muitas sementes por lóculo. 
Distribuição e habitat: Ocorre em Minas Gerais, Rio de Janeiro e São Paulo, em formações florestais de altitudes elevadas.

Material selecionado examinado: Brasil, São Paulo: Lavrinhas, 06/IV/1995, Goldenberg 76 \& Belinello (UEC); Paranapiacaba, 28/II/1923, Hoehne s.n. (UEC 69450); São Paulo, 25/II/1931, Hoehne s.n. (SP 27184); "Serra da Mantiqueira", 16/III/1939, Kuhlmann \& Gehrt s.n. (SP 40046).

A distinção entre $M$. valtherii e $M$. eichlerii Cogn. foi baseada em características extremamente variáveis, como base das folhas e número de nervuras. Estas espécies deverão ser sinonimizadas e o binômio $M$. valtherii foi adotado por ser o mais antigo.

Espécies de ocorrência duvidosa no Estado de São Paulo

Os materiais relativos às espécies Miconia eriodonta DC. e M. lurida Cogn., citadas por Hoehne (1922), não foram localizadas nos herbários paulistas e Jardim Botânico do Rio de Janeiro.

\section{Agradecimentos}

Os autores agradecem ao Dr. V. Bittrich pela leitura do Abstract e à Sra. Esmeralda Z. Borghi pelo acabamento das ilustrações.

\section{Referências bibliográficas}

Baumgratz, J.F.A. 1980. Miconias do município do Rio de Janeiro. Seção Miconia DC. (Melastomataceae). Rodriguésia 32: 73-95.

Baumgratz, J.F.A. 1982. Miconias do Estado do Rio de Janeiro. Seção Tamonea (Aubl.) Cogn. (Melastomataceae). Archos. Jard. Bot. 26: 69-86.

Baumgratz. J.F.A. 1984. Miconias do Estado do Rio de Janeiro. Seção Chaenanthera Naud. (Melastomataceae). Rodriguésia 36: 45-58.

Cogniaux, A. 1887/1888. Miconia, Melastomataceae. in: C.F.P. Martius \& A.G. Eichler (eds.), Flora Brasiliensis. vol. 14, pte. 4. Frid. Fleischer, Lipsiae.

Cogniaux, A. 1891. Melastomataceae. In: A. \& C. de Candolle (eds.), Monographiae Phanerogamarum. vol. 7. G. Masson, Paris.

Hickey, L.J. 1973. Classification of the architecture of dicotyledonous leaves. Amer. J. Bot. 60: 17-33.

Hoehne, F.C. 1922. Melastomáceas dos Hervários: Horto "Oswaldo Cruz", Museu Paulista, Comissão de Linhas Telegráficas Estratégicas de Mato-Grosso ao Amazonas, Jardim Botânico do Rio de Janeiro, etc. Anexos Mem. Inst. Butantan, secc. Bot. I(5): 1-198.

Howard, R.A. \& Kellogg, A. 1986. Nomenclatural Notes on Miconia (Melastomataceae). J. Arn. Arb. 67: 233-255.

Judd, W.S. 1986. Taxonomic studies in the Miconieae (Melastomataceae). I. Variation in inflorescence position. Brittonia 38: 150-161.

Judd, W.S. 1989. Taxonomic studies in the Miconieae (Melastomataceae). III. Cladistic analysis of axillary-flowered taxa. Ann. Missouri Bot. Gard. 76: 476-495. 
Judd, W.S. \& Skean Jr., J.D. 1991. Taxonomic studies in the Miconieae (Melastomataceae). IV. Generic realignments among terminal flowered taxa. Bull. Florida Mus. Nat. Hist 36: 25-84.

Pereira, E. 1964. Flora do Estado da Guanabara IV. Melastomataceae II. Miconieae. Gênero Miconia. Archos. Jard. Bot. 18: 183-214.

Renner, S.S. 1993. Phylogeny and classification of the Melastomataceae and Memecylaceae. Nord. J. Bot. 13: $519-540$.

Triana, J. 1871. Melastomataceae. Trans. Linn. Soc. London 28: 1-188.

Wurdack, J.J. 1960. Certamen Melastomataceis VI. Phytologia 7: 233-243.

Wurdack, J.J. 1962. Melastomataceae of Santa Catarina. Sellowia 14: 109-217.

Wurdack, J.J. 1973. Melastomataceae. In T. Lasser (ed.), Flora de Venezuela. vol. 8. Instituto Botanico, Caracas.

Wurdack, J.J. 1974. Certamen Melastomataceis XXIII. Phytologia 29: 135-151.

Wurdack, J.J. 1980. Melastomataceae. In G. Harling \& B. Sparre (eds.), Flora of Equador. vol. 13. University Göteborg and Riksmuseum, Stockholm.

Wurdack, J.J. 1986. Atlas of hairs for tropical Melastomataceae. Smithsonian Contrib. Bot. 63: 1-80.

Wurdack, J.J. \& Renner, S.S. 1993. Melastomataceae. In Van Rijn (ed.), Flora of the Guianas. Koeltz Scientific Books, Koenigstein.

\section{Nota}

Este trabalho possui uma versão ilustrada disponível em rede, cujo endereço é "http://www.bdt.org.br/bdt/ miconia". 

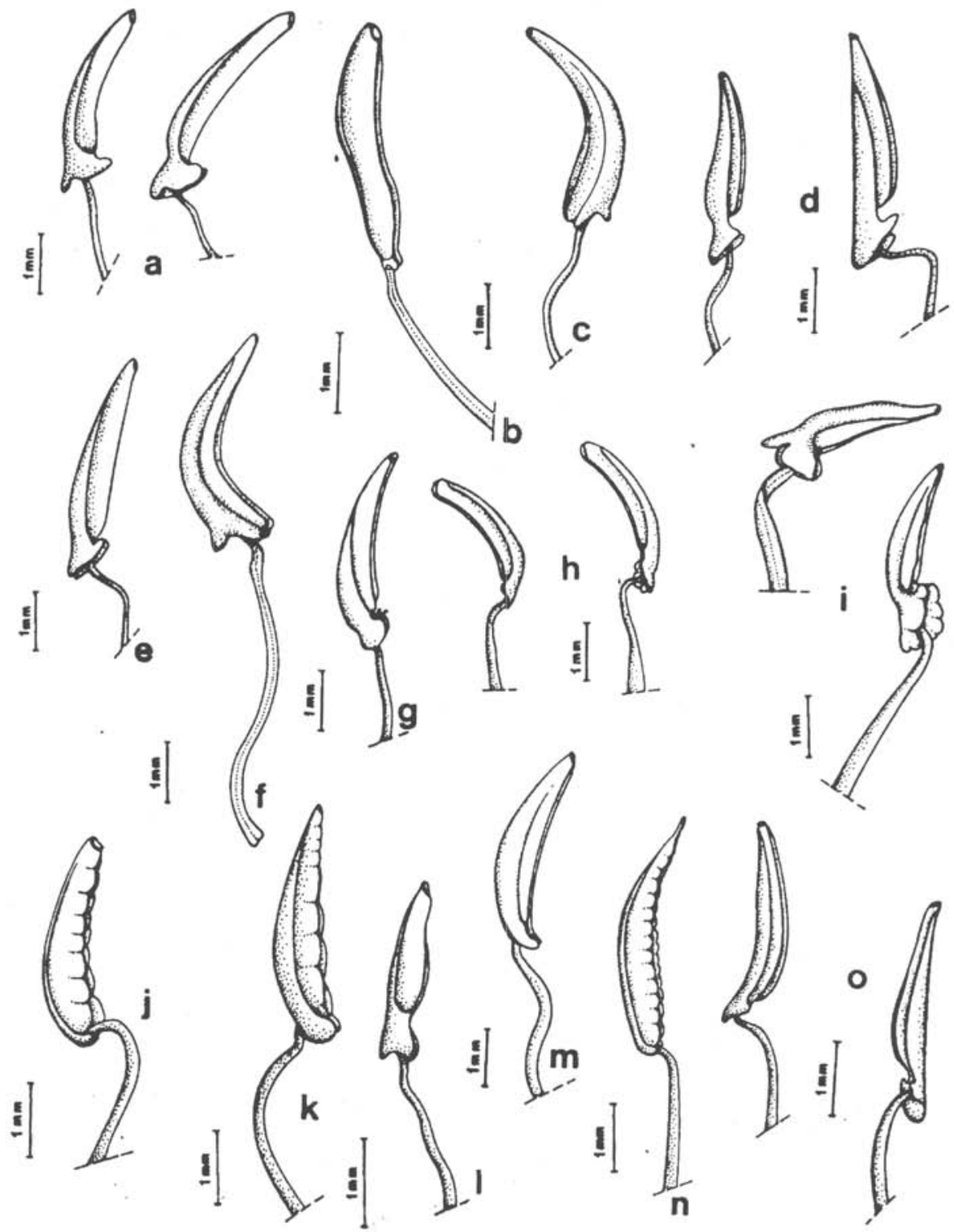

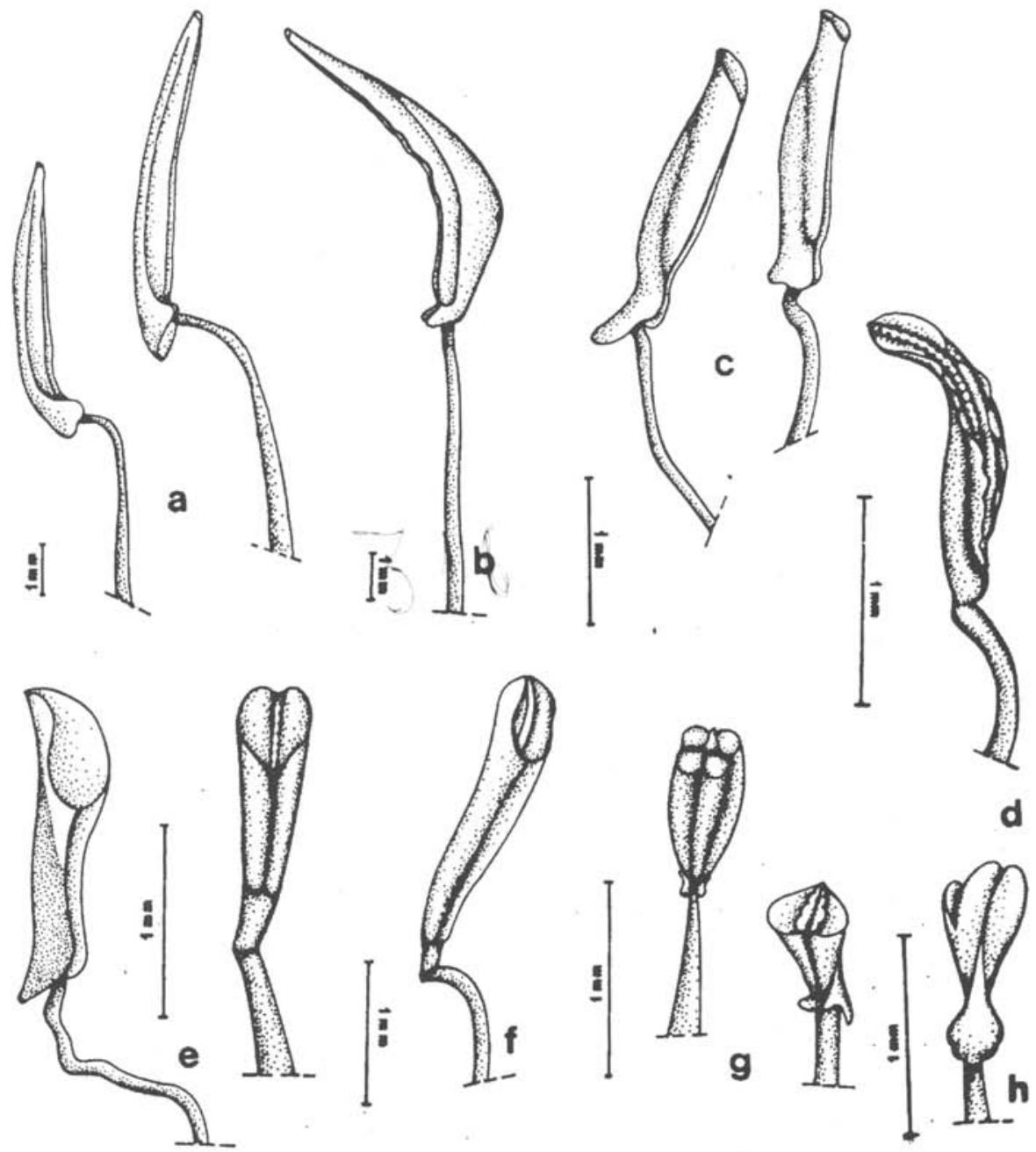

Figura 2. Estames de Miconia: a. M. jucunda (à esquerda ante-pétalo; à direita ante-sépalo); b. $M$. dodecandra; c. M. ligustroides (à esquerda ante-pétalo; à direita ante-sépalo); d. M. urophylla; e. $M$. latecrenata (à esquerda ante-pétalo; à direita ante-sépalo); f. M. sellowiana; g. M. theaezans; h. M. inconspicua (à esquerda da escala ante-pétalo; à direita ante-sépalo). 